\title{
Poverty, old age and gender in nineteenth-century England: the case of Hertfordshire
}

\author{
NIGEL GOOSE*
}

ABSTRACT. This article examines the relative incidence of poverty among the elderly in nineteenth-century Hertfordshire with special reference to gender. Both national and local sources are employed to highlight the particular difficulties experienced by the elderly, male poor under the New Poor Law, and the short and long term problems they faced as a result of seasonal unemployment and an overstocked labour market. For elderly women, the extent to which their poverty was relieved by employment in cottage industry, almshouse accommodation, the continuing receipt of out-relief and a higher incidence of family support are examined to provide an assessment of the manner in which poverty was gendered in the nineteenth century.

\section{INTRODUCTION}

Much is made in the academic literature of the plight of elderly women, their prominence in relief rolls of the sixteenth, seventeenth and eighteenth centuries, with only a rare appreciation, notably by Margaret Pelling in her analysis of the Norwich census of the poor of 1570 , of the possibility that in some circumstances men may have been equally, or even more, vulnerable. ${ }^{1}$ The continuing susceptibility of elderly women to poverty in nineteenth-century England has been forcefully argued by Pat Thane. It was due to the facts that they tended to live longer; that they were more severely affected by marriage breakdown than men; that there were more single and widowed mothers than fathers with children to support; that they were less likely to re-marry; that their work opportunities were more limited; and that, when they could work, their wages were

\footnotetext{
* School of Humanities, University of Hertfordshire.
} 
generally much lower than those of men, most commonly one-half or even one-third. ${ }^{2}$ All of this might be true, but in the midst of this over-arching concern for poor, elderly women, the plight of poor old men tends to be overlooked. For if there were particular difficulties associated with being elderly, poor and female in gender, there were also difficulties associated with being old, poor and male. ${ }^{3}$ In certain respects too there were possible channels of relief, both formal and informal, that were open to women but that - while not denied to men-were less readily available to them. Furthermore, in some local or regional contexts the problems facing poor old men may have been particularly severe, while economic opportunities may have provided a cushion, at least against the depths of poverty, that were only available to women. Finally, there are strong indications that the situation of elderly men worsened considerably with the introduction of the New Poor Law in 1834, particularly in the economic and social circumstances that prevailed in many of the southern, agricultural counties of England. This article will explore their situation with special reference to the county of Hertfordshire.

Hertfordshire is a small county of approximately 400,000 acres, with a population in 1801 of 97,393 , rising to 167,298 by mid-century and 250,080 by 1901, an overall increase of 159 per cent compared to the national growth rate of 266 per cent. At the start of the century Hertfordshire accounted for 1.1 per cent of the national total, but its somewhat slower rate of growth finds reflection in a reduction in its share in every decade except the 1890s, until by 1901 it accounted for just 0.77 per cent. Although it achieved a healthy surplus of births over deaths, Hertfordshire was a net exporter of population, net emigration standing at 55,085 in the period 1851-1901, accounting for 46 per cent of the natural growth achieved within that period. ${ }^{4}$ Hertfordshire was as 'typical' an arable county as one will find, described in a report to the Board of Agriculture in 1795 as 'the first corn county in the kingdom', with only a very limited interest in livestock farming. ${ }^{5}$ Farming practice and productivity varied, with the lighter soils of the south of the county responding more rapidly to London demand. ${ }^{6}$ By no means highly urbanized, it nevertheless possessed a flourishing network of small towns, particularly concentrated in the south-west of the county, exhibited evidence in the early nineteenth century of the growth of consumer and service trades and benefited from good north-south road connections as well as from the passage of the Grand Union Canal through the southwest. The south and west were also notable for its thriving cottage and small-factory industry in the form of the straw-plait and hat trades. Additional industrial development took the form of silk production and paper-making (again towards the south), malt-making (centred upon 
Ware), and the related development of substantial brewing concerns in a number of Hertfordshire towns, while the north of the county remained largely agrarian. ${ }^{7}$ The agrarian basis of the county, with an almost exclusively male full-time labour force, and the existence of opportunities for female employment in the straw-plait and hat trades, are of central relevance to the issue of gender, old age and poverty in Hertfordshire in the nineteenth century.

\section{THE NEW POOR LAW, AGE AND GENDER}

The members of the 1832 Poor Law Commission were obsessed with the perceived problem of the pauperization of able-bodied men and the subsequent Poor Law Amendment Act of 1834 reflected these concerns. Its basic terms, of course, are well known: it ordered the withdrawal of outdoor relief from able-bodied men who, if they were to be relieved at all, were only to be offered the workhouse, the conditions of which were to be such as to render the position of the pauper 'less eligible' than (that is, inferior to) that of the poorest independent labourer. Outdoor relief could only be granted in cases of 'sudden and urgent necessity', sickness or to meet funeral expenses. The condition of the female population seemed very much a secondary concern, and on the whole women were considered as dependants, whose classification under the New Poor Law would simply mirror that of their husband. Widows were to be allowed outdoor relief during the first six months of their widowhood, as were all widows with legitimate dependent children. Relief to widows was extended beyond the six-month period by legislation in 1846 and 1848 . According to the Poor Law Amendment Act of 1834, the 'impotent' poor of both sexes - those who were not able to maintain themselves by their labour - were to be relieved on the old terms, in their own homes through receipt of regular payments, albeit at minimal levels which would not offend the ratepayer. ${ }^{8}$ This gave scope for the continued payment of out-relief to the elderly and incapacitated in general, and to women in particular if they were deemed to be impotent, providing another potential avenue for discrimination by gender. ${ }^{9}$ Indeed, there is growing evidence to suggest that even under the Old Poor Law outdoor relief was granted to men more grudgingly than it was to women, and greater pressure was placed upon men to find work, however menial. ${ }^{10}$ Reporting to the Royal Commission of 1832, the overseers of Hatfield in Hertfordshire showed that they had already adopted a more severe attitude to able-bodied applicants for relief, among whom 'All persons, except women ... shall be employed in task work', while in nearby Welwyn male applicants were employed in 'preparing materials, in mending (very much in lifting) the roads, and in scouring 
ditches ... on such terms as to labour and wages as to make it the least desirable of any in the parish ...', while women did not have to work for relief. ${ }^{11}$ Similarly, it was reported to the Select Committee on Agriculture in 1833 that in Shropshire and Herefordshire relief outside of the workhouse was only given to 'widows and old people, but not to any labouring man able to work, except in case of sickness'. There were clearly local and regional variations, however, for a further report on Kent and Sussex suggests that unemployed labourers continued to receive outdoor relief on the eve of the passage of the 1834 Act. $^{12}$

What happened in practice after 1834 is both transparent and controversial. It is transparent with regard to the proportion of claimants who were granted outdoor and indoor relief nationally, and it is at least vaguely transparent with regard to the proportions receiving relief of any kind by gender. On the former score, while in 1834 it was estimated that 8.8 per cent of the population were in receipt of relief, the quinquennial figures for 1850-1914, which are averages of the numbers relieved on 1 January and 1 July each year, show that this figure had fallen to 5.7 per cent by 1850 , that the proportion stabilized at between 4.3 per cent and 4.8 per cent during the next 20 years, and that it then began a further steady decline to just 2 per cent by 1914 . These trends were largely governed by changes in outdoor relief, however, for the proportion of the population in receipt of indoor relief remained essentially stable across this sixty-year period. Throughout these years, outdoor relief remained the senior partner: at the start of the period the ratio between outdoor and indoor paupers stood at 6.5-7 to 1; by the early twentieth century it stood at 2 to 1, again with most of the decline coming after 1870, the year which inaugurated a new drive against out-relief, whether paid to men or to women. ${ }^{13}$

New figures, based upon three-year averages of data centred upon successive census years, extracted from 15 annual reports of the Poor Law Board and Local Government Board, are presented in the first column of Tables 1 and 2, and these show similar long-term trends. They confirm that, nationally, the decline in relief was largely the product of declining outdoor relief, while the proportion of the population in the workhouse remained remarkably stable. In Hertfordshire, where relief in general was provided to a higher proportion of the population throughout the period, most of the decline was again due to changes in outdoor payments, although here the proportion receiving relief in the workhouse also fell slightly towards the end of the nineteenth century.

In terms of gender, although historians of the New Poor Law are quite clear that women formed the bulk of recipients, it is much harder to find firm figures. ${ }^{14}$ Tables 1 and 2 provide a summary across the second half of 
TABLE 1

Poor relief in England and Wales, 1850-1852 to 1900-1902: percentages relieved and averages of the numbers of adults recorded 1 January and 1 July each year ${ }^{a}$

\begin{tabular}{|c|c|c|c|c|c|c|c|c|c|c|c|c|c|c|}
\hline & \multirow{2}{*}{$\begin{array}{l}\% \text { pop. } \\
\text { relieved }\end{array}$} & \multirow{2}{*}{$\begin{array}{l}\text { No. of } \\
\text { Unions }\end{array}$} & \multicolumn{4}{|c|}{ Adult males } & \multicolumn{4}{|c|}{ Adult females } & \multicolumn{4}{|c|}{ Sex ratio } \\
\hline & & & Able & Not able & Lunatic & Total & Able & Not able & Lunatic & Total & Able & Not able & Lunatic & Total \\
\hline \multicolumn{15}{|l|}{$1850-1852$} \\
\hline Indoor & 0.62 & $590 / 597^{b}$ & 5,860 & 18,901 & 2,037 & 26,797 & 11,362 & 13,912 & 2,544 & 27,818 & 52 & 136 & 80 & 96 \\
\hline Outdoor & 4.64 & $590 / 597$ & 31,249 & 100,412 & 4,109 & 135,769 & 89,948 & 211,370 & 4,797 & 306,115 & 35 & 48 & 86 & 44 \\
\hline Total & 5.26 & $590 / 597$ & 37,109 & 119,312 & 6,146 & 162,567 & 101,310 & 225,281 & 7,341 & 333,932 & 37 & 53 & 84 & 49 \\
\hline \multicolumn{15}{|l|}{$1860-1862$} \\
\hline Indoor & 0.62 & $649 / 651^{c}$ & 5,717 & 26,872 & 3,510 & 36,099 & 13,715 & 20,796 & 4,857 & 39,367 & 42 & 129 & 72 & 92 \\
\hline Outdoor & 3.82 & $649 / 651$ & 31,437 & 101,100 & 10,532 & 143,068 & 94,584 & 231,284 & 13,393 & 339,261 & 33 & 44 & 79 & 42 \\
\hline Total & 4.44 & $649 / 651$ & 37,154 & 127,971 & 14,042 & 179,166 & 108,299 & 252,080 & 18,250 & 378,628 & 34 & 51 & 77 & 47 \\
\hline \multicolumn{15}{|l|}{$1870-1872$} \\
\hline Indoor & 0.67 & 647 & 8,839 & 37,245 & 5,189 & 51,273 & 14,560 & 25,415 & 6,858 & 46,833 & 61 & 147 & 76 & 109 \\
\hline Outdoor & 3.73 & 647 & 33,284 & 111,992 & 15,802 & 161,077 & 103,793 & 258,771 & 19,645 & 382,209 & 32 & 43 & 80 & 42 \\
\hline Total & 4.40 & 647 & 42,123 & 149,237 & 20,991 & 212,350 & 118,353 & 284,185 & 26,503 & 429,041 & 36 & 53 & 79 & 49 \\
\hline \multicolumn{15}{|l|}{$1880-1882$} \\
\hline Indoor & 0.71 & 647 & 8,744 & 48,729 & 6,746 & 64,218 & 13,719 & 33,942 & 8,973 & 56,632 & 64 & 144 & 75 & 113 \\
\hline Outdoor & 2.35 & 647 & 16,875 & 77,027 & 20,334 & 114,235 & 66,262 & 190,926 & 25,906 & 283,094 & 25 & 40 & 78 & 40 \\
\hline Total & 3.06 & 647 & 25,618 & 125,756 & 27,079 & 178,453 & 79,980 & 224,868 & 34,879 & 339,726 & 32 & 56 & 78 & 53 \\
\hline \multicolumn{15}{|l|}{ 1890-1892 } \\
\hline Indoor & 0.64 & 648 & 11,626 & 53,352 & 6,910 & 71,887 & 13,419 & 36,975 & 8,999 & 59,392 & 87 & 144 & 77 & 121 \\
\hline Outdoor & 1.94 & 648 & 13,009 & 74,946 & 25,653 & 113,608 & 54,392 & 187,017 & 32,476 & 273,885 & 24 & 40 & 79 & 41 \\
\hline Total & 2.58 & 648 & 24,635 & 128,298 & 32,563 & 185,495 & 67,811 & 223,992 & 41,474 & 333,276 & 36 & 57 & 79 & 56 \\
\hline \multicolumn{15}{|l|}{ 1900-1902 } \\
\hline Indoor & 0.68 & $646 / 8$ & 17,665 & 63,063 & 7,477 & 88,204 & 17,127 & 43,920 & 8,919 & 69,966 & 103 & 144 & 84 & 126 \\
\hline Outdoor & 1.75 & $646 / 8$ & 10,598 & 77,739 & 33,661 & 121,997 & 48,434 & 201,988 & 41,330 & 291,751 & 22 & 38 & 81 & 42 \\
\hline Total & 2.43 & $646 / 8$ & 28,262 & 140,801 & 41,137 & 210,200 & 65,560 & 245,908 & 50,249 & 361,717 & 43 & 57 & 82 & 58 \\
\hline
\end{tabular}

a All of those relieved are included in the calculation of the percentage of the population. The data for adult males and females exclude children under 16, and also exclude those classified as vagrants, for whom no gender breakdown is available. From July 1900 the data also exclude a (relatively) small number of outdoor 'insane' paupers who were not housed in institutions and for whom no gender breakdown is given.

$c$ The numbers of Unions rose to 597 in the period.

Source: British Parliamentary Papers, Annual Reports of the Poor Law Board and Local Government Board. 
TABLE 2

Poor relief in Hertfordshire, 1850-1852 to 1900-1902: percentages relieved and averages of the numbers of adults recorded 1 January and 1 July each year

\begin{tabular}{|c|c|c|c|c|c|c|c|c|c|c|c|c|c|c|}
\hline & \multirow{2}{*}{$\begin{array}{l}\% \text { pop. } \\
\text { relieved }\end{array}$} & \multirow{2}{*}{$\begin{array}{l}\text { No. of } \\
\text { Unions }\end{array}$} & \multicolumn{4}{|c|}{ Adult males } & \multicolumn{4}{|c|}{ Adult females } & \multicolumn{4}{|c|}{ Sex ratio } \\
\hline & & & Able & Not able & Lunatic & Total & Able & Not able & Lunatic & Total & Able & Not able & Lunatic & Total \\
\hline \multicolumn{15}{|l|}{ 1850-1852 } \\
\hline Indoor & 0.95 & 13 & 193 & 445 & 36 & 674 & 194 & 213 & 47 & 454 & 99 & 209 & 77 & 148 \\
\hline Outdoor & 5.04 & 13 & 488 & 1,331 & 63 & 1,882 & 1,150 & 2,878 & 77 & 4,105 & 42 & 46 & 82 & 46 \\
\hline Total & 5.99 & 13 & 681 & 1,776 & 99 & 2,556 & 1,344 & 3,091 & 124 & 4,559 & 51 & 57 & 80 & 56 \\
\hline \multicolumn{15}{|l|}{$1860-1862$} \\
\hline Indoor & 0.86 & 12 & 114 & 465 & 27 & 606 & 151 & 184 & 54 & 388 & 75 & 253 & 50 & 156 \\
\hline Outdoor & 5.65 & 12 & 552 & 1,365 & 134 & 2,051 & 1,267 & 2994 & 167 & 4,428 & 44 & 46 & 80 & 46 \\
\hline Total & 6.51 & 12 & 666 & 1,830 & 161 & 2,657 & 1,418 & 3,178 & 221 & 4,816 & 47 & 58 & 73 & 55 \\
\hline \multicolumn{15}{|l|}{$1870-1872$} \\
\hline Indoor & 0.85 & 12 & 134 & 570 & 43 & 747 & 130 & 208 & 51 & 389 & 103 & 274 & 84 & 192 \\
\hline Outdoor & 5.32 & 12 & 498 & 1,570 & 178 & 2,246 & 1,234 & 3,317 & 188 & 4,739 & 40 & 47 & 95 & 47 \\
\hline Total & 6.17 & 12 & 632 & 2,140 & 221 & 2,993 & 1,364 & 3,525 & 239 & 5,128 & 46 & 61 & 92 & 58 \\
\hline \multicolumn{15}{|l|}{$1880-1882$} \\
\hline Indoor & 0.80 & 12 & 81 & 565 & 32 & 678 & 93 & 212 & 40 & 345 & 87 & 267 & 80 & 197 \\
\hline Outdoor & 3.70 & 12 & 220 & 1,177 & 198 & 1,595 & 769 & 2644 & 255 & 3,668 & 29 & 45 & 78 & 43 \\
\hline Total & 4.50 & 12 & 301 & 1,742 & 230 & 2,273 & 862 & 2,856 & 295 & 4,013 & 35 & 61 & 78 & 57 \\
\hline \multicolumn{15}{|l|}{ 1890-1892 } \\
\hline Indoor & 0.68 & 12 & 95 & 535 & 31 & 661 & 102 & 222 & 44 & 368 & 93 & 241 & 70 & 180 \\
\hline Outdoor & 3.25 & 12 & 170 & 1,117 & 227 & 1,514 & 604 & 2,622 & 322 & 3,548 & 28 & 43 & 70 & 43 \\
\hline Total & 3.93 & 12 & 265 & 1,652 & 258 & 2,175 & 706 & 2,844 & 366 & 3,916 & 38 & 58 & 70 & 56 \\
\hline \multicolumn{15}{|l|}{$1900-1902$} \\
\hline Indoor & 0.60 & 12 & 117 & 511 & 26 & 654 & 111 & 263 & 42 & 415 & 105 & 194 & 62 & 158 \\
\hline Outdoor & 2.64 & 12 & 101 & 1,056 & 291 & 1,448 & 395 & 2,677 & 369 & 3,441 & 26 & 39 & 79 & 42 \\
\hline Total & 3.24 & 12 & 218 & 1,567 & 317 & 2,102 & 506 & 2,940 & 411 & 3,856 & 43 & 53 & 77 & 55 \\
\hline
\end{tabular}

Notes: All of those relieved are included in the calculation of the percentage of the population. The data for adult males and females exclude children under 16, and also exclude those classified as vagrants, for whom no gender breakdown is available. From July 1900 the data also exclude a (relatively) small number of outdoor 'insane' paupers who were not housed in institutions and for whom no gender breakdown is given.

Source: British Parliamentary Papers, Annual Reports of the Poor Law Board and Local Government Board. 
the nineteenth century, for England and Wales and for Hertfordshire. The right-hand column of Table 1 reveals an overall sex ratio (males per 100 females) for all adults, indoor and outdoor, fluctuating between 47 and 58 , and hence roughly two adult women were relieved to every one adult male across the later nineteenth century, the ratio of men to women rising slightly after 1870-1872. The same calculation for Hertfordshire in Table 2 produces ratios of a similar order of magnitude, although the proportion of males was slightly higher between 1850-1852 and 1870-1872 than was the case nationally. In terms of outdoor relief, both nationally and in Hertfordshire, the sex ratio was lower still, within the narrow range 40-44 nationally, and 42-47 for Hertfordshire.

There are two ways of reading these figures, and the one that is most commonly adopted is to regard them as a reflection of the greater vulnerability and need for relief among women across the later nineteenth century, which involves acceptance of the data as a true reflection of the relative incidence of poverty by gender. But an alternative reading would be to suggest that the figures are not simply an objective reflection of the extent of poverty experienced respectively by adult men and women, but also reflect the greater willingness of nineteenth-century poor law officers to grant relief to women, and the harsher attitude adopted towards men. Such a reading would fit far better with the philosophy of the Report of the 1832 Poor Law Commission, enshrined in the 1834 Poor Law Amendment Act, and there is a good deal of both official and anecdotal support for such a reading. If we look at the categories under which men and women were eligible for relief under the New Poor Law, they were not only different by gender but women had many more paths to relief than did men, particularly in the case of out-relief. For women could qualify for relief in their own right, as well as through their family or marital status, whereas males who were widowers or were single parents had no claim to relief on either of these criteria. As Lyn Hollen Lees has put it, 'The rules of welfare entitlement worked out by the Poor Law Commission and its successor, the Poor Law Board, were shaped by attitudes toward gender. Men worked and took care of their families; women cared for children and needed help if they lacked a husband. ${ }^{15}$ There was nothing new in such gendered attitudes, which - as we have seen above - had been apparent in Hertfordshire and elsewhere before the 1834 Act was framed, but the clear intention was to enforce these distinctions with a new rigour, firmly underpinned by legislative authority.

There is considerable dispute as to how rigorously the principles of the 1834 Act were applied, particularly with respect to able-bodied men. On the one side stands Karel Williams, who argues from national statistics that 'In the twenty years after 1834, a line of exclusion was drawn against 
able-bodied men', an interpretation supported by Apfel and Dunkley's study of Bedfordshire. ${ }^{16}$ In contrast Anne Digby has argued on the basis of her Norfolk evidence that able-bodied men continued to receive outdoor relief, often disguised as payment for personal or family sickness. ${ }^{17}$ How typical this was is debatable, however, given that Norfolk was one of those exceptional areas initially excluded from the Act, where eighteenthcentury incorporations were left intact. ${ }^{18}$ Nevertheless, Lyn Lees also finds that able-bodied men continued to receive support-at least in the 1840 s - in the six county towns whose examinations she sampled, as well as in a select number of London Unions in 1849-1850. She is clear, however, that 'Both in the capital and in the county towns, men were somewhat less likely to be given outrelief than were female applicants, but similar proportions of each group were offered care in an institution. ${ }^{19}$ A return made to parliament of the number of people relieved on the grounds of being out of work or in aid of wages during the tenth week of the Christmas quarter of 1852 produces a total relieved for want of work of 8,041 in England and Wales, a figure which in many parishes included dependents, as well as those relieved both in and out of the workhouse, forming a relatively small proportion of the total of 840,000 or so registered on relief on 1 January in the years 1850-1852. The number of ablebodied adult males relieved outdoors on account of 'want of work or other causes' on 1 January 1852 stood at just 4,108, and at 2,677 on 1 July the same year, while successive returns between 1853 and 1890 produce lower figures still for most years, only occasionally amounting to more than half of a percentage point of the total number of paupers. ${ }^{20}$ Furthermore, the Outdoor Labour Test Order of 1842 and the Outdoor Relief Regulation Order of 1852 introduced the notion, long favoured in parts of Hertfordshire, of out-relief for able-bodied men only in return for work, and by 1871 these regulations applied to roughly half of the Poor Law Unions in England and Wales. ${ }^{21}$

Tables 1 and 2 provide further evidence of the problems men faced under the New Poor Law. For if men formed a minority of the total found eligible for relief, and a smaller proportion of those granted relief outdoors, the proportions who were male and able-bodied receiving outdoor relief were smaller still. For England and Wales the sex ratios of ablebodied adults granted outdoor relief stood at 32-35 from 1850-1852 to 1870-1872, and then fell further to just 22-25 between 1880-1882 and 1900-1902. For Hertfordshire the figure was slightly higher in the earlier years, at $40-42$, but fell just as dramatically to 26-29 towards the end of the century. By the last thirty years of the nineteenth century, therefore, only approximately one able-bodied recipient of out-relief in four was a man. 
The figures for indoor relief are equally instructive. For England and Wales, the overall sex ratio of those consigned collectively by local Boards of Guardians to the workhouse swung from a small bias towards females in the early 1850 s and early 1860 s (sex ratios 92-96) to a larger bias towards men by the end of the century (sex ratios 121-126). In Hertfordshire, however, there was a consistent and substantial bias towards men, the sex ratios rising from 148 in 1850-1852, to a peak of 197 in 1880-1882, before falling back once again to 158 by the end of the century. But the figures for those deemed not able-bodied who were relieved in the workhouse are even more interesting. Although successive poor law reports fail to identify exactly what the terms 'able-bodied' and 'not able-bodied' meant, it has been suggested that 'Most Unions regarded all paupers between the ages of sixteen and seventy as being 'able-bodied' if they were not permanently incapacitated', and hence the non-able bodied can be equated very largely with the elderly. ${ }^{22}$ This view receives support from the introduction to the annual poor law reports on 1 January 1891 of a new category of ablebodied adult male and female indoor pauper - those who were 'temporarily disabled' - and it is quite clear from comparison of numbers recorded in successive reports around this date that this was a new sub-division of the category previously deemed able-bodied, and not a sub-division of those deemed not to be able. ${ }^{23}$ If it is indeed the case that the great majority of those classified as not able-bodied were elderly, then the sex ratio of this category in receipt of indoor relief takes on a new significance. For in England and Wales as a whole there was a consistent and substantial majority of men in this category, the sex ratio ranging from 129 to 147 , while in Hertfordshire the sex ratio averaged as much as 240 across the second half of the nineteenth century, peaking in 1870-1872 at 274, and only falling back to 194 in the very early years of the twentieth century. To a considerable degree in England and Wales as a whole, therefore, but particularly starkly in the county of Hertfordshire, the experience among the elderly of residence in the workhouse was heavily gendered. ${ }^{24}$

Further evidence from the 1851 and 1891 census returns for Hertfordshire, and from admissions to the Hatfield Union Workhouse between 1836 and 1861, supports this interpretation of the national poor law data. Table 3 presents data for all 13 Hertfordshire workhouses in 1851, when the census was taken on 30 March. The overall sex ratio, at 150 , is almost identical to that calculated from the published poor law reports, but among the elderly $(60+)$ it stood at 236 in the county as a whole, rising to 256 for the very elderly $(70+)$, and was thus even higher than the figures for those classed in the reports as 'not able'. In the most purely agricultural districts in the county, Bishop's Stortford and Royston, the figures reached 385 and 400 respectively for those aged $60+$. 
TABLE 3

Age and sex profile of Hertfordshire workhouse inmates, 1851: all ages, age 60+ and age 70+

\begin{tabular}{|c|c|c|c|c|c|c|c|c|c|c|c|c|c|c|c|c|c|c|}
\hline \multirow[b]{2}{*}{ Union } & \multicolumn{4}{|c|}{ All Ages } & \multicolumn{7}{|c|}{$60+$} & \multicolumn{7}{|c|}{$70+$} \\
\hline & Total & $M$ & $F$ & $\begin{array}{c}\text { Sex } \\
\text { ratio }\end{array}$ & Total & $\%$ & $M$ & $\%$ & $F$ & $\%$ & $\begin{array}{c}\text { Sex } \\
\text { ratio }\end{array}$ & Total & $\%$ & $M$ & $\%$ & $F$ & $\%$ & $\begin{array}{r}\text { Sex } \\
\text { ratio }\end{array}$ \\
\hline Barnet & 145 & 83 & 62 & 134 & 36 & 24.8 & 23 & 27.7 & 13 & 21.0 & 177 & 19 & 13.1 & 11 & 13.3 & 8 & 12.9 & 138 \\
\hline Berkhamsted & 61 & 39 & 22 & 177 & 30 & 49.2 & 22 & 56.4 & 8 & 36.4 & 275 & 10 & 16.4 & 9 & 23.1 & 1 & 4.5 & 900 \\
\hline Bishop's Stortford & 327 & 182 & 145 & 126 & 63 & 19.3 & 50 & 27.5 & 13 & 9.0 & 385 & 30 & 9.2 & 23 & 12.6 & 7 & 4.8 & 329 \\
\hline Hatfield & 108 & 60 & 48 & 125 & 31 & 28.7 & 23 & 38.3 & 8 & 16.7 & 288 & 14 & 13.0 & 9 & 15.0 & 5 & 10.4 & 180 \\
\hline Hemel Hempstead & 109 & 74 & 35 & 211 & 53 & 48.6 & 36 & 48.6 & 17 & 48.6 & 212 & 39 & 35.8 & 28 & 37.8 & 11 & 31.4 & 255 \\
\hline Hertford & 117 & 68 & 49 & 139 & 33 & 28.2 & 24 & 35.3 & 9 & 18.4 & 267 & 18 & 15.4 & 14 & 20.6 & 4 & 8.2 & 350 \\
\hline Hitchin & 173 & 118 & 55 & 215 & 68 & 39.3 & 50 & 42.4 & 18 & 32.7 & 278 & 30 & 17.3 & 23 & 19.5 & 7 & 12.7 & 329 \\
\hline Royston & 235 & 155 & 80 & 194 & 55 & 23.4 & 44 & 28.4 & 11 & 13.8 & 400 & 28 & 11.9 & 24 & 15.5 & 4 & 5.0 & 600 \\
\hline St Albans & 233 & 133 & 100 & 133 & 106 & 45.5 & 68 & 51.1 & 38 & 38.0 & 179 & 74 & 31.8 & 49 & 36.8 & 25 & 25.0 & 196 \\
\hline Ware & 127 & 65 & 62 & 105 & 34 & 26.8 & 19 & 29.2 & 15 & 24.2 & 127 & 20 & 15.7 & 10 & 15.4 & 10 & 16.1 & 100 \\
\hline Watford & 249 & 151 & 98 & 154 & 85 & 34.1 & 59 & 39.1 & 26 & 26.5 & 227 & 50 & 20.1 & 39 & 25.8 & 11 & 11.2 & 355 \\
\hline TOTAL & 2,057 & 1,234 & 823 & 150 & 615 & 29.9 & 432 & 35.0 & 183 & 22.2 & 236 & 345 & 16.8 & 248 & 20.1 & 97 & 11.8 & 256 \\
\hline Herts. population & 173,962 & 86,465 & 87,497 & 99 & 13,382 & 7.7 & 6,353 & 7.4 & 7,029 & 8.0 & 90 & 5,223 & 3.0 & 2,444 & 2.8 & 2,779 & 3.2 & 88 \\
\hline $\begin{array}{l}\% \text { of age group in } \\
\text { workhouse }\end{array}$ & 1.18 & 1.43 & 0.94 & & 4.60 & & 6.80 & & 2.60 & & & 6.61 & & 10.15 & & 3.49 & & \\
\hline
\end{tabular}

Source: Hertfordshire Census Enumerators Books, 1851, The National Archive, Kew, H0 107/1701-1716, and see note 25.

${ }^{a}$ Indicates an infinite number, the divisor being zero. 
Furthermore, it is equally clear from these data that the elderly were massively over-represented among workhouse residents compared to their significance in the population as a whole: while 7.7 per cent of the population of Hertfordshire were aged 60+ in 1851, this group formed 29.9 per cent of all workhouse residents. For males, however, the situation was worse still, for fully 35 per cent of male workhouse residents were aged 60 or over, compared to just 7.3 per cent among the population of the county at large. In Hertfordshire in 1851, 6.8 per cent of the total male population aged 60 or over were workhouse inmates, while for those aged 70 or over the proportion stood in excess of 10 per cent. ${ }^{25}$

As Table 4 indicates, by 1891 (census date 5 April) while the proportion of the population as a whole in the county's workhouses had fallen by almost half, from 1.18 to 0.67 per cent, the proportion of the elderly population in workhouses had fallen by less than a third, from 4.6 to 3.09 per cent. For men the decline was smaller still, and hence the sex ratio for men in general and elderly men in particular stood even higher in 1891 than it had 40 years earlier, at 172 and 269 respectively. Still in 18914.89 per cent of the county's male population aged $60+$ were in the workhouse on census night, and 7.58 per cent of those aged 70 or over. In proportion to their number in the population, elderly men were more than three times as likely as were elderly women to find themselves in the workhouse on census night in $1891 .^{26}$

\section{THE PROBLEMS OF AGRICULTURAL LABOUR}

Admissions to the Hatfield Union Workhouse for 1836-1861 also show a preponderance of men among the elderly inmates, accounting for 616 out of 767 admissions, or 80.3 per cent. ${ }^{27}$ But the snapshot provided by the census and the Hatfield admissions register also reveals the prominence of agricultural labourers among male workhouse inmates. Ten of the thirteen Hertfordshire workhouses in 1851 provide unambiguous occupational information, and of the 706 males with an occupational designation 517 (73 per cent) were agricultural workers; the proportion among those aged $60+$ was also $73 . .^{28}$ Occupational data are available from the Hatfield Union workhouse only for the years 1836-1847, and here 552 men out of 643 with a recorded occupation, or almost 86 per cent, are described as 'labourer' ${ }^{29}$ By 1891 , the census data suggest that the proportion of male workhouse inmates from the agricultural sector had fallen, for only 48 per cent now fell into that category, or 52 per cent among those aged 60 and over. $^{30}$

Agricultural labouring was a strenuous occupation. An international report cited recently by Roderick Floud suggests that a day's ploughing 
TABLE 4

Age and sex profile of Hertfordshire workhouse inmates, 1891: all ages, age 60+ and age 70+

\begin{tabular}{|c|c|c|c|c|c|c|c|c|c|c|c|c|c|c|c|c|c|c|}
\hline \multirow[b]{2}{*}{ Union } & \multicolumn{4}{|c|}{ All Ages } & \multicolumn{7}{|c|}{$60+$} & \multicolumn{7}{|c|}{$70+$} \\
\hline & Total & $M$ & $F$ & $\begin{array}{c}\text { Sex } \\
\text { ratio }\end{array}$ & Total & $\%$ & $M$ & $\%$ & $F$ & $\%$ & $\begin{array}{c}\text { Sex } \\
\text { ratio }\end{array}$ & Total & $\%$ & $M$ & $\%$ & $F$ & $\%$ & $\begin{array}{c}\text { Sex } \\
\text { ratio }\end{array}$ \\
\hline Berkhamsted & 77 & 56 & 21 & 267 & 36 & 46.8 & 30 & 53.6 & 6 & 28.6 & 500 & 25 & 32.5 & 20 & 35.7 & 5 & 23.8 & 400 \\
\hline Bishop's Stortford & 197 & 122 & 75 & 163 & 92 & 46.7 & 66 & 54.1 & 26 & 34.7 & 254 & 57 & 28.9 & 39 & 32.0 & 18 & 24.0 & 217 \\
\hline Buntingford & 69 & 40 & 29 & 138 & 25 & 36.2 & 17 & 42.5 & 8 & 27.6 & 213 & 14 & 20.3 & 10 & 25.0 & 4 & 13.8 & 250 \\
\hline Hemel Hempstead & 93 & 67 & 26 & 258 & 54 & 58.1 & 37 & 55.2 & 17 & 65.4 & 218 & 40 & 43.0 & 27 & 40.3 & 13 & 50.0 & 208 \\
\hline Hertford & 139 & 88 & 51 & 173 & 59 & 42.4 & 41 & 46.6 & 18 & 35.3 & 228 & 33 & 23.7 & 21 & 23.9 & 12 & 23.5 & 175 \\
\hline Hitchin & 140 & 86 & 54 & 159 & 72 & 51.4 & 55 & 64.0 & 17 & 31.5 & 324 & 47 & 33.6 & 34 & 39.5 & 13 & 24.1 & 262 \\
\hline Royston & 95 & 47 & 48 & 98 & 32 & 33.7 & 14 & 29.8 & 18 & 37.5 & 78 & 21 & 22.1 & 7 & 14.9 & 14 & 29.2 & 50 \\
\hline St Albans & 172 & 111 & 61 & 182 & 90 & 52.3 & 68 & 61.3 & 22 & 36.1 & 309 & 60 & 34.9 & 41 & 36.9 & 19 & 31.1 & 216 \\
\hline Ware & 126 & 85 & 41 & 207 & 60 & 47.6 & 49 & 57.6 & 11 & 26.8 & 445 & 42 & 33.3 & 32 & 37.6 & 10 & 24.4 & 320 \\
\hline Watford & 241 & 142 & 99 & 143 & 91 & 37.8 & 70 & 49.3 & 21 & 21.2 & 333 & 58 & 24.1 & 41 & 28.9 & 17 & 17.2 & 241 \\
\hline Welwyn & 25 & 17 & 8 & 213 & 11 & 44.0 & 7 & 41.2 & 4 & 50.0 & 175 & 7 & 28.0 & 4 & 23.5 & 3 & 37.5 & 133 \\
\hline Hertfordshire & 215,179 & 104,525 & 110,654 & 94 & 20,707 & 9.6 & 9,520 & 9.1 & 11,187 & 10.1 & 85 & 8,354 & 3.9 & 3,746 & 3.6 & 4,608 & 4.2 & 81 \\
\hline $\begin{array}{l}\% \text { of population } \\
\text { in workhouse }\end{array}$ & 0.67 & 0.87 & 0.48 & & 3.09 & & 4.89 & & 1.55 & & & 4.97 & & 7.58 & & 2.84 & & \\
\hline
\end{tabular}

Notes: Barnet workhouse was transferred from Hertfordshire to Middlesex in 1857 (cf. Table 3).

Source: Hertfordshire Census Enumerators Books, 1891, The National Archive, Kew, RG 12/1052-1127, and see note 25. 
uses at least twice as much energy as working as a tailor or carpenter. ${ }^{31}$ The work is predominantly conducted outdoors, in all weathers and for long hours, which might often be preceded and succeeded by a long walk from and to home. It is often back-breaking, is frequently dangerous and involves the use of potentially hazardous equipment and proximity to unpredictable animals. Arthritic and rheumatic conditions, and incapacitation through injury, are relatively common among farm workers. As Floud concludes, 'It is for these reasons that few country-dwellers have the romantic view of farm life which so many city-dwellers came to have in the nineteenth and twentieth centuries; farm work is far from a pastoral idyll. ${ }^{32}$

If farm work in general is arduous, it becomes increasingly so with age. Analysis of the St Albans Registrar's District of Hertfordshire reveals that 200 out of 2,160 agricultural workers listed in the 1851 census were aged 60 or over, 49 of whom were in the workhouse on census night, nearly a quarter of the total. Of the rest, one must question how many - particularly those in their eighties and nineties-could manage or command regular work, or could even work at all. ${ }^{33}$ Pat Thane suggests, quoting the agricultural trade unionist Joseph Arch, that old people carried on working for as long as they were able, and also that 'Old men could work longest in agriculture', although 'As they aged further, this tapered off until [work] was available only at harvest time ...' ${ }^{34}$ Analyses of national sample data from the 1851 and 1881 censuses, excluding those in institutions, indicates that slightly over 70 per cent of men aged 65 and over claimed to be 'economically active' at both dates, with easily the heaviest concentration in agricultural work. ${ }^{35}$ Although those living on independent means are included in this figure, virtually 30 per cent listed in these censuses were without an occupation. ${ }^{36}$ Similar calculations for Hertfordshire in 1851 and 1881, again including those of independent means among the inactive population, produce figures of 29 per cent and 22 per cent for the two dates respectively. ${ }^{37}$ The 1851 data, calculated for the ancient county from census enumerators' books, shows that for all three age categories, $60+, 65+$ and $70+$, excluding those of independent means, the Royston and Bishop's Stortford Unions exhibit the highest percentages inactive, and these were the two most wholly agricultural unions and almost certainly, in general, the least agriculturally advanced. ${ }^{38}$

The capacity of individual elderly men for work is impossible to assess across the board, though census returns provide occasional glimpses of their difficulties, such as the case of William Swain, a widower of Preston Green, aged 67, described in 1851 as a 'late blacksmith past work', or John Bonstead, aged 78, of Back Lane also in the Hamlet of Preston, 
'worn out labourer'. Descriptions provided in workhouse listings suggest a diversity of experience. In the Bishop's Stortford workhouse in 1891, 15 farm labourers are specifically described as 'retired', and while 12 of these were aged between 62 and 79, one was 30, another 34 and a third 42. Two retired tailors are listed too, aged 41 and 63, two retired carpenters, aged 45 and 67, while of 23 retired general labourers two were in their thirties, one in his forties and four in their fifties. In the Hatfield Workhouse at the same date, four of the nine retired agricultural labourers were under 60 years of age, one just 40. The Hatfield Union Admissions and Discharges register provides a graphic record of individual misfortune, of numerous diseased, injured and broken limbs, of illnesses of infinite variety from chillblains to cholera, of burns and blindness, idiocy and idleness, of destitution and demoralization. 'Old age' was not an epithet reserved only for those over 60 years, even if the rule adopted in the 1881 census report was to regard all workhouse residents over 60 as 'having almost certainly retired' and those below this age as probably still in employment. But the descriptions contained in the register are insufficiently precise, often potentially overlapping, for any more than an impressionistic analysis, even if the skew towards the elderly in general, and elderly men in particular, is quite clear. ${ }^{39}$

A range of sources suggest that elderly men were competing in an overstocked labour market in Hertfordshire in the second and third quarters of the nineteenth century. Of 3,659 admissions to the Hatfield Union Workhouse between 1836 and 1861, 770 (21 per cent) record want of work, in addition to the numerous entries that simply record 'destitution'. Despite the recent suggestion that 'winter unemployment in English agriculture is likely to have been modest even in the nineteenth century, ${ }^{40}$ there is considerable evidence that seasonal unemployment was a problem for predominantly agricultural counties such as Hertfordshire, a situation which is amply reflected in monthly trends in workhouse admissions. ${ }^{41}$ It is clear too from the 'answers to rural queries' compiled by the Poor Law Commissioners and included in the 1834 report, which are extant for 18 Hertfordshire parishes. Question 5 asked how many agricultural labourers there were in the parish, and question 6 how many were generally out of employment in summer or winter. St Margaret near Ware produced the most optimistic response, 'None out of Employment, Summer or Winter', but there were only 19 labourers to find work for in this parish. Elsewhere, every parish that answered these questions recorded higher unemployment in winter than in summer. In Welwyn only $10-15$ were reported to be unemployed in winter out of 404 labourers, or 2-4 per cent. But in Redbourn, out of 250 labourers over the age of 10, 6 were unemployed weekly in the summer months, but 'about 
18 ' weekly in the six winter months, an unemployment rate of 7 per cent, identical to the winter total in St Ippollitts. For St Peter it was reported that there were about 340 labourers over the age of 10 , just 6 of whom were unemployed in summer, but 25 in winter, again just over 7 per cent. In St Michael, 16 were reported to be unemployed weekly in winter out of 227, 7 per cent again, but here it was noted that unemployed labourers 'are employed in digging gravel, repairing roads, or any useful work', no doubt to prevent them becoming a burden on the poor rate. ${ }^{42}$ The situation in Cheshunt, with 'about 700' labourers, was particularly bad. In summer 42 were unemployed, 6 per cent of the total, but in winter the figure rose to 117 , nearly 17 per cent, while in Stevenage the estimate of 'from 12 to 20' constituted 13-22 per cent of the total number of labourers. The return for Hertingfordbury is particularly interesting. Here the Rector Robert J. Eden reported that 9 of the 111 labourers over the age of 20 were unemployed in winter, but added that these were 'generally old men, or young ones that are idle'. In Shenley again, it was 'the worst workmen or worst characters' that were generally put out of work in winter. Hatfield provided no return, but when interviewed by the Commissioners the rector reported 90-100 out of work in winter, 40-50 of whom were employed in planting by the Marquess of Salisbury, while 'a great many only find work at haytime and harvest'. ${ }^{43}$ If this Hatfield example provides evidence of the ameliorating effect of paternalism, and that from Shenley a reminder of the attack on idleness that the New Poor Law embodied, Eden's report from Hertingfordbury again suggests the particular vulnerability to seasonal unemployment of elderly men, which is reinforced by indications that labourers' wages might be varied according to their capacity. ${ }^{44}$

The seasonality of employment can also be inferred from the data in the annual reports of the Poor Law and Local Government Boards, for it finds reflection in the disparity between those recorded as claiming indoor and outdoor relief on 1 January and 1 July. Table 5 presents the ratios of paupers at these two dates calculated for three-year averages at the start of each decade, from 1850-1852 to 1900-1902, for England and Wales and for Hertfordshire respectively. A number of interesting features appear in this table, the first of which is the consistently much higher ratio, in both England and Wales and in Hertfordshire, for indoor as compared with outdoor relief: outdoor pauperism rose quite marginally in the winter months, indoor pauperism far more substantially, suggesting that it was the workhouse that provided the main mechanism for coping with the problem of seasonal unemployment. Second, while the figures for outdoor relief suggest that men suffered more than women from seasonal factors, the disparity between the sexes is far greater for indoor relief, and hence it 
TABLE 5

Ratio of paupers relieved, 1 January to 1 July, England and Wales and Hertfordshire, 1850-1852 to 1900-1902

\begin{tabular}{|c|c|c|c|c|c|c|c|c|c|c|}
\hline \multicolumn{11}{|c|}{ England and Wales } \\
\hline & \multicolumn{5}{|c|}{ Indoor } & \multicolumn{5}{|c|}{ Outdoor } \\
\hline & Total & $M$ & $F$ & $<16$ & Vagrant & Total & $M$ & $F$ & $<16$ & Vagrant \\
\hline $1850-1852$ & 1.22 & 1.33 & 1.18 & 1.17 & 1.41 & 1.05 & 1.06 & 1.03 & 1.07 & 1.20 \\
\hline $1860-1862$ & 1.15 & 1.24 & 1.13 & 1.12 & 0.73 & 1.02 & 1.03 & 1.01 & 1.03 & 0.90 \\
\hline $1870-1872$ & 1.18 & 1.28 & 1.13 & 1.14 & 0.87 & 1.10 & 1.12 & 1.06 & 1.14 & 1.30 \\
\hline $1880-1882$ & 1.13 & 1.23 & 1.09 & 1.08 & 0.94 & 1.05 & 1.06 & 1.03 & 1.07 & 0.84 \\
\hline 1890-1892 & 1.14 & 1.25 & 1.09 & 1.06 & 1.00 & 1.04 & 1.05 & 1.03 & 1.04 & 1.07 \\
\hline \multirow[t]{3}{*}{$1900-1902$} & 1.11 & 1.19 & 1.05 & 1.03 & 1.29 & 1.02 & 1.03 & 1.01 & 1.02 & 1.60 \\
\hline & \multicolumn{3}{|c|}{ Males } & \multicolumn{2}{|c|}{ Females } & \multicolumn{3}{|c|}{ Males } & \multicolumn{2}{|c|}{ Females } \\
\hline & Able & \multicolumn{2}{|c|}{ Not able } & Able & Not able & Able & \multicolumn{2}{|c|}{ Not able } & Able & Not able \\
\hline $1850-1852$ & 2.42 & 1.1 & & 1.42 & 1.05 & 1.22 & 1.0 & & 1.10 & 1.01 \\
\hline $1860-1862$ & 1.80 & 1.1 & & 1.30 & 1.07 & 1.08 & 1.0 & & 1.01 & 1.00 \\
\hline $1870-1872$ & 1.92 & 1.2 & & 1.33 & 1.08 & 1.47 & 1.0 & & 1.16 & 1.03 \\
\hline $1880-1882$ & 1.71 & 1.2 & & 1.25 & 1.06 & 1.37 & 1.0 & & 1.08 & 1.01 \\
\hline 1890-1892 & 1.53 & 1.2 & & 1.18 & 1.07 & 1.14 & 1.0 & & 1.05 & 1.03 \\
\hline $1900-1902$ & 1.38 & 1.1 & & 1.14 & 1.03 & 1.18 & 1.0 & & 1.03 & 1.01 \\
\hline \multicolumn{11}{|c|}{ Hertfordshire } \\
\hline
\end{tabular}

\begin{tabular}{|c|c|c|c|c|c|c|c|c|c|c|}
\hline & \multicolumn{5}{|c|}{ Indoor } & \multicolumn{5}{|c|}{ Outdoor } \\
\hline & Total & $M$ & $F$ & $<16$ & Vagrant & Total & $M$ & $F$ & $<16$ & Vagrant \\
\hline $1850-1852$ & 1.47 & 1.81 & 1.28 & 1.31 & 2.00 & 1.06 & 1.08 & 1.05 & 1.07 & $\_^{a}$ \\
\hline $1860-1862$ & 1.36 & 1.59 & 1.27 & 1.27 & 0.26 & 1.06 & 1.08 & 1.05 & 1.08 & 0.00 \\
\hline $1870-1872$ & 1.39 & 1.59 & 1.22 & 1.32 & 0.81 & 1.09 & 1.12 & 1.05 & 1.13 & 0.00 \\
\hline $1880-1882$ & 1.19 & 1.45 & 1.13 & 1.13 & 0.61 & 1.03 & 1.05 & 1.01 & 1.04 & $-^{a}$ \\
\hline $1890-1892$ & 1.23 & 1.45 & 1.08 & 1.11 & 0.88 & 1.06 & 1.08 & 1.04 & 1.08 & 0.00 \\
\hline \multirow[t]{3}{*}{ 1900-1902 } & 1.18 & 1.27 & 1.05 & 1.12 & 1.33 & 1.02 & 1.05 & 1.01 & 1.03 & 0.00 \\
\hline & \multicolumn{3}{|c|}{ Males } & \multicolumn{2}{|c|}{ Females } & \multicolumn{3}{|c|}{ Males } & \multicolumn{2}{|c|}{ Females } \\
\hline & Able & \multicolumn{2}{|c|}{ Not able } & Able & Not able & Able & \multicolumn{2}{|c|}{ Not able } & Able & Not able \\
\hline $1850-1852$ & 4.27 & \multicolumn{2}{|c|}{1.40} & 1.73 & 1.0 & 1.23 & \multicolumn{2}{|c|}{1.02} & 1.07 & 1.03 \\
\hline $1860-1862$ & 3.65 & \multicolumn{2}{|c|}{1.36} & 1.73 & 1.04 & 1.21 & \multicolumn{2}{|c|}{1.04} & 1.12 & 1.02 \\
\hline $1870-1872$ & 2.99 & \multicolumn{2}{|c|}{1.45} & 1.60 & 1.09 & 1.32 & \multicolumn{2}{|c|}{1.08} & 1.11 & 1.04 \\
\hline 1880-1882 & 3.50 & \multirow{2}{*}{\multicolumn{2}{|c|}{$\begin{array}{l}1.33 \\
1.33\end{array}$}} & 1.33 & 1.07 & 1.15 & \multicolumn{2}{|c|}{1.05} & 1.03 & 1.01 \\
\hline $1890-1892$ & 2.78 & & & 1.32 & 1.01 & 1.28 & 1.0 & & 1.06 & 1.05 \\
\hline 1900-1902 & 1.72 & \multicolumn{2}{|c|}{1.20} & 1.19 & 1.00 & 1.45 & \multicolumn{2}{|c|}{1.05} & 1.05 & 1.01 \\
\hline
\end{tabular}

a Indicates an infinite number, the divisor being zero.

Source: British Parliamentary Papers, Annual Reports of the Poor Law Board and Local Government Board. 
was men more than women for whom seasonal unemployment was more likely to result in workhouse residence. Third, while the figures for outdoor relief are quite similar in Hertfordshire to those calculated for England and Wales as a whole, for indoor relief the Hertfordshire ratios stand considerably above the national ones, for both sexes, but again far more noticeably for men. Fourth, it was able-bodied men whose number in the workhouse rose most considerably on 1 January, no doubt reflecting the wider spread of unemployment throughout the workforce in the winter months, and this was again much more marked in Hertfordshire than it was nationally. That said, as the number of men in the workhouse who were deemed 'not able' was considerably larger that the able category, in terms of absolute numbers there were more additional not able (and therefore elderly) men in the workhouse in January as compared to July, for both Hertfordshire and for England and Wales, in every period except for 1850-1852. ${ }^{45}$ Finally, both for Hertfordshire and nationally, the ratios for indoor relief fell with considerable consistency over time - for men, women and children - perhaps providing an index of the decline of seasonal unemployment in general, and the decline of seasonal unemployment in the agricultural sector, itself undergoing long-term contraction, in particular.

\section{GENDER AND ALTERNATIVESOURCES OF RELIEF}

To exacerbate the difficulties men faced due to discrimination by poor law officers, a particular reluctance to grant outdoor relief, their decreasing capacity for labour as they aged, a more circumscribed labour market for the elderly and the problems involved in agricultural work in general and its seasonality in particular, there may also have been fewer alternative sources of relief for them. In agricultural areas, the range of occupations was considerably more restricted than in many industrial and/or urban areas, particularly in corn-growing counties such as Hertfordshire where lighter duties, such as the minding or tending of livestock, were in short supply. Furthermore, there were occupations available to women, both in Hertfordshire and more generally, to which they were fitted by long years of domestic experience, such as charring, the taking in of laundry, sewing or the provision of lodgings - not richly rewarded occupations, perhaps, but a means of generating at least a modest income nonetheless. Furthermore, in Hertfordshire, as well as in neighbouring Bedfordshire, Buckinghamshire and parts of Essex, there was another group of occupations that was very predominantly a female preserve, and that was in the straw-plait and hat trades. Straw-plaiting and hat-making were thriving across much of western and south-western Hertfordshire prior to 
their late-nineteenth-century decline, and could be practised into a ripe old age, and their incidence across the county is shown in Table $6 .{ }^{46} \mathrm{In}$ many villages and small towns they provided occupations that employed proportions of both single and married women that compare favourably with the cotton textile districts of industrial Lancashire or the Staffordshire potteries; they produced a skewed sex ratio in these areas through sex-selective net migration; and in many of the areas where they predominated there was a tendency for females to be less well-represented, certainly in the younger age groups, among workhouse populations. ${ }^{47}$

Another source of relief was the almshouse, for accommodation within which the eligible poor could apply as places became available to the charity's trustees, or to the relevant local authority in cases where responsibility had devolved upon them. ${ }^{48}$ Here too there was a distinct tendency for women to be favoured over men. A survey of Hertfordshire almshouses founded before 1834 -both registered and unregistered charities - reveals that only 12 per cent of the 322 available places were specifically devoted to men, while 56 per cent were devoted to women, and the rest were unspecified by gender. ${ }^{49}$ The 59 foundations identified provided spaces for 298 individual inmates, 12 couples and 21 families. If we count the number specified by gender, add 12 to each to allow for couples and 21 to each to allow for heads of families, then (generously in relation to men) divide the 80 unallocated in a ratio of 3 men to 5 women, the totals achieved are 101 men and 272 women, virtually all of whom were above the age of 60 . Reference back to Table 3, which identified the age and sex profile of workhouse inmates in 1851, shows that while the number of men in almshouses constituted well under a quarter of the number aged $60+$ housed in workhouses across the county (101 compared to 432), there were considerably more women in almshouses than in workhouses (272 compared to 183). ${ }^{\mathbf{5 0}}$

The greater ease with which women gained poor law pensions may have rendered them a financial asset to any household they joined, but they brought other advantages too. ${ }^{51}$ Female domestic skills may have meant that they were better able to look after themselves than were elderly widowers, but these same skills may also have rendered women more attractive to their families as co-residents. The evidence of working-class autobiographies indicates how rare it was for men to contribute significantly to housework, ${ }^{52}$ while analysis of household structures in two contrasting regions of Hertfordshire-the St Albans and Royston Unions - offers strong support for such a hypothesis. The former, in the south-west of the county, was a strong straw-plait and hat area, relatively highly urbanized, situated on major trade routes and within the London orbit, while the latter, in the north-east, had only a minor interest in straw 
TABLE 6

Employment in the straw industry in Hertfordshire, 1851

\begin{tabular}{|c|c|c|c|c|c|c|c|}
\hline \multirow[b]{2}{*}{ Registration district } & \multicolumn{4}{|c|}{ Population } & \multicolumn{3}{|c|}{$\begin{array}{l}\text { Percentages of occupied } \\
\text { population in straw trades }\end{array}$} \\
\hline & Total & $M$ & $F$ & Sex ratio & All & $M$ & $F$ \\
\hline Berkhamsted & 11,532 & 5,466 & 6,066 & 90 & 32 & 8 & 62 \\
\hline St Albans & 17,991 & 8,591 & 9,400 & 91 & 24 & 4 & 49 \\
\hline Hemel Hempstead & 13,094 & 6,325 & 6,769 & 93 & 29 & 8 & 59 \\
\hline Hitchin & 24,519 & 12,049 & 12,470 & 97 & 22 & 4 & 56 \\
\hline Hatfield \& Welwyn & 8,484 & 4,330 & 4,154 & 104 & 8 & 0 & 27 \\
\hline Royston & 14,481 & 7,375 & 7,106 & 104 & 4 & 0 & 18 \\
\hline Watford & 18,747 & 9,232 & 9,515 & 97 & 4 & 0 & 13 \\
\hline Hertford & 14,517 & 7,316 & 7,201 & 102 & 2 & 0 & 8 \\
\hline Ware & 16,445 & 8,323 & 8,122 & 102 & 0 & 0 & 1 \\
\hline Bishop's Stortford & 13,074 & 6,500 & 6,574 & 99 & 0 & 0 & 1 \\
\hline Edmonton & 4,815 & 2,379 & 2,436 & 98 & 0 & 0 & 1 \\
\hline Barnet & 5,675 & 2,902 & 2,773 & 105 & 1 & 0 & 4 \\
\hline Hertfordshire & 163,374 & 80,788 & 82,586 & 98 & 13 & 2 & 35 \\
\hline
\end{tabular}

Source: Hertfordshire Census Enumerators’ Books, 1851, The National Archive, Kew, H0 $107 / 1701-1716$.

plaiting, was very predominantly agricultural, was less well-connected and far more removed from the immediate influence of the capital. The St Albans Registration District in 1851, excluding institutions and inns and similar commercial establishments, comprised 16,568 individuals in 3,576 households; that part of the Royston registration district that lay within Hertfordshire (institutions but not inns excluded) comprised 14,280 individuals in 2,953 households. In the St Albans region, 21 per cent of all households were extended by the inclusion of at least one relative over and above members of the nuclear family; in the Royston region the figure was almost identical, at 20 per cent. The categories of kin represented, and their distribution by sex, are shown in Table 7. Both reveal an overall skew in the sex ratio in favour of women, more marked in the St Albans region than in the Royston district, and particularly in town compared with countryside in both areas. Across the two districts together, the sex ratio of resident kin stood at 72 . Among siblings, the female bias was quite dramatic in the St Albans region, where employment opportunities in the straw industry were abundant, while it was far less marked - though still apparent - in Royston. Among parents, grandparents and parents-in-law, however, the sex ratio was very similarly skewed in both areas. In St Albans 112 households were vertically 
TABLE 7

Categories of kin in Hertfordshire, 1851: St Albans and Royston regions

\begin{tabular}{|c|c|c|c|c|c|c|}
\hline & \multicolumn{3}{|c|}{ St Albans region } & \multicolumn{3}{|c|}{ Royston region } \\
\hline & Urban & Rural & Total & Urban & Rural & Total \\
\hline Aunt & 5 & 4 & 9 & 0 & 8 & 8 \\
\hline Brother & 28 & 31 & 59 & 16 & 63 & 79 \\
\hline Brother-in-law & 8 & 18 & 26 & 0 & 23 & 23 \\
\hline Cousin (m) & 0 & 0 & 0 & 1 & 2 & 3 \\
\hline Cousin (f) & 7 & 6 & 13 & 2 & 2 & 4 \\
\hline Daughter-in-law & 11 & 21 & 32 & 2 & 36 & 38 \\
\hline Father & 2 & 9 & 11 & 1 & 17 & 18 \\
\hline Father-in-law & 6 & 17 & 23 & 1 & 14 & 15 \\
\hline Grandfather & 0 & 0 & 0 & 0 & 1 & 1 \\
\hline Grandaughter & 71 & 137 & 208 & 22 & 141 & 163 \\
\hline Grandson & 72 & 124 & 196 & 11 & 143 & 154 \\
\hline Gt Grandaughter & 3 & 2 & 5 & 0 & 0 & 0 \\
\hline Gt Grandson & 1 & 3 & 4 & 0 & 1 & 1 \\
\hline Gt Nephew & 5 & 1 & 6 & 0 & 3 & 3 \\
\hline Gt Niece & 0 & 5 & 5 & 0 & 0 & 0 \\
\hline Mother & 22 & 27 & 49 & 8 & 42 & 50 \\
\hline Mother-in-law & 16 & 18 & 34 & 0 & 26 & 26 \\
\hline Nephew & 47 & 46 & 93 & 9 & 58 & 67 \\
\hline Niece & 55 & 68 & 123 & 14 & 64 & 78 \\
\hline Relative (m) & 0 & 0 & 0 & 0 & 2 & 2 \\
\hline Relative (f) & 0 & 2 & 2 & 0 & 0 & 0 \\
\hline Sister & 103 & 76 & 179 & 16 & 74 & 90 \\
\hline Sister-in-law & 23 & 31 & 54 & 4 & 30 & 34 \\
\hline Son-in-law & 4 & 42 & 46 & 1 & 34 & 35 \\
\hline Step-mother & 0 & 2 & 2 & 0 & 0 & 0 \\
\hline Step-sister & 1 & 0 & 1 & 0 & 0 & 0 \\
\hline Uncle & 0 & 0 & 0 & 0 & 6 & 6 \\
\hline Total & 490 & 690 & 1,180 & 108 & 790 & 898 \\
\hline Male & 173 & 291 & 464 & 40 & 367 & 407 \\
\hline Female & 317 & 399 & 716 & 68 & 423 & 491 \\
\hline Sex ratio & 55 & 73 & 65 & 59 & 87 & 83 \\
\hline Parents (and in-laws) ${ }^{a}$ & 46 & 73 & 119 & 10 & 100 & 110 \\
\hline Male & 8 & 26 & 34 & 2 & 32 & 34 \\
\hline Female & 38 & 47 & 85 & 8 & 68 & 76 \\
\hline Sex ratio & 21 & 55 & 40 & 25 & 47 & 45 \\
\hline Siblings (and in-laws) ${ }^{b}$ & 163 & 156 & 319 & 36 & 190 & 226 \\
\hline Male & 36 & 49 & 85 & 16 & 86 & 102 \\
\hline Female & 127 & 107 & 234 & 20 & 104 & 124 \\
\hline Sex ratio & 28 & 46 & 36 & 80 & 83 & 82 \\
\hline
\end{tabular}

Source: Hertfordshire Census Enumerators' Books, 1851, The National Archive, Kew, H0 107/1701-1716.

${ }^{a}$ Includes step-parents and grandparents.

${ }^{b}$ Includes step-sister. 
extended to include parents or parents-in-law, encompassing 119 individuals - but of these only 34 were men compared to 85 women. In Royston 107 households were vertically extended, encompassing 110 individuals, of whom 34 were men and 76 were women. Taking the two areas together the sex ratio for this, predominantly elderly, category of resident kin stood at just $42 .{ }^{53}$

The potential contribution of these female kin to household chores and perhaps particularly to child care must surely have a bearing upon this strong disparity between the sexes, while the fact that in the St Albans region the skew was more marked than that identified by Michael Anderson in his national 1851 census sample may have much to do with the far greater possibility here that female relatives could contribute additional income to the family budget from employment in straw plaitand hat-making. ${ }^{54}$ Among the elderly, however, female relatives were clearly and consistently favoured in preference to men, and out of all proportion to their greater overall number that resulted from the fact of higher female longevity. If we take the catchment area of St Albans and Royston workhouses as roughly corresponding to these two districts, then a total of 68 elderly male relatives on census night in 1851 were housed with their families and 112 found themselves in the workhouse, while for elderly women 161 resided with their families and just 49 in the workhouse. $^{55}$

HERTFORDSHIRE AND VICTORIAN ENGLAND

The county of Hertfordshire - predominantly rural, corn-growing, lacking in large towns and with particularly good female employment opportunities across half the county - may not be typical, and even within it there existed different manifestations of those 'rural Englands' to which Barry Reay has recently given eloquent testimony ${ }^{56}$ From the point of view of poor old men, Hertfordshire may have been particularly ill-favoured. It is well established that male wages rates in the Midlands and the north stood considerably above those in much of the south and East Anglia, and if rates in Hertfordshire were not at the very bottom of the scale, they did not stand far above it. ${ }^{57}$ David Thomson's analysis of the workhouse data available from the published census reports also indicates a clear regional discrepancy, and in particular a north-south divide. ${ }^{58}$

As a southern corn-growing county Hertfordshire may also have been particularly susceptible to seasonal unemployment, as is suggested by comparison of seasonal fluctuations in workhouse occupancy in Hertfordshire compared with England and Wales as a whole, which is underlined more clearly by the data in Tables 8 and $9 .^{59}$ Despite 
TABLE 8

Indoor and outdoor relief in England and Wales, 1851: seasonal variation and sex ratios, by county

\begin{tabular}{|c|c|c|c|c|c|c|c|c|c|c|c|c|}
\hline \multicolumn{7}{|c|}{ Indoor relief } & \multicolumn{6}{|c|}{ Outdoor relief } \\
\hline & \multicolumn{2}{|c|}{ \% of pop. relieved } & \multirow{2}{*}{$\begin{array}{c}\text { Ratio } \\
\text { Jan.: July }\end{array}$} & \multicolumn{3}{|c|}{ Sex ratio, adults } & \multicolumn{2}{|c|}{$\%$ of pop. relieved } & \multirow{2}{*}{$\begin{array}{c}\text { Ratio } \\
\text { Jan. } \text { July }\end{array}$} & \multicolumn{3}{|c|}{ Sex ratio, adults } \\
\hline & 1 Jan. & 1 July & & 1 Jan. & 1 July & Total & $1 \mathrm{Jan}$ & 1 July & & 1 Jan. & 1 July & Total \\
\hline Beds. & 0.79 & 0.48 & 1.63 & 149 & 102 & 130 & 4.97 & 4.75 & 1.05 & 48 & 46 & 47 \\
\hline Berks. & 1.19 & 0.81 & 1.47 & 110 & 100 & 106 & 5.44 & 5.22 & 1.04 & 56 & 57 & 56 \\
\hline Cambs. & 1.15 & 0.69 & 1.67 & 176 & 131 & 159 & 6.82 & 6.47 & 1.05 & 47 & 43 & 45 \\
\hline Cheshire & 0.31 & 0.29 & 1.08 & 109 & 104 & 107 & 3.17 & 3.13 & 1.01 & 42 & 43 & 42 \\
\hline Cornwall & 0.57 & 0.50 & 1.15 & 44 & 42 & 43 & 4.59 & 4.41 & 1.04 & 35 & 34 & 35 \\
\hline Cumb. & 0.67 & 0.64 & 1.04 & 77 & 75 & 76 & 3.80 & 3.54 & 1.07 & 37 & 37 & 37 \\
\hline Derby. & 0.35 & 0.34 & 1.04 & 82 & 88 & 85 & 2.36 & 2.36 & 1.00 & 45 & 44 & 44 \\
\hline Devon & 0.62 & 0.54 & 1.16 & 85 & 73 & 80 & 6.45 & 6.22 & 1.04 & 49 & 49 & 49 \\
\hline Dorset & 0.93 & 0.66 & 1.40 & 88 & 84 & 86 & 7.83 & 7.26 & 1.08 & 47 & 45 & 46 \\
\hline Durham & 0.28 & 0.26 & 1.07 & 99 & 99 & 99 & 3.93 & 3.84 & 1.03 & 33 & 32 & 33 \\
\hline Gloucs. & 0.82 & 0.65 & 1.26 & 80 & 83 & 81 & 5.25 & 5.07 & 1.03 & 45 & 46 & 46 \\
\hline Hereford & 0.76 & 0.62 & 1.22 & 82 & 69 & 76 & 6.91 & 6.48 & 1.07 & 54 & 53 & 53 \\
\hline Herts. & 1.18 & 0.76 & 1.55 & 167 & 129 & 151 & 5.09 & 4.78 & 1.07 & 47 & 46 & 46 \\
\hline Hunts. & 1.08 & 0.65 & 1.66 & 196 & 142 & 174 & 6.19 & 5.92 & 1.05 & 44 & 45 & 45 \\
\hline Kent & 1.14 & 0.91 & 1.25 & 121 & 104 & 113 & 4.26 & 4.02 & 1.06 & 43 & 41 & 42 \\
\hline Lancs. & 0.42 & 0.40 & 1.06 & 89 & 89 & 89 & 3.27 & 3.07 & 1.06 & 47 & 44 & 46 \\
\hline Leics. & 0.55 & 0.57 & 0.96 & 128 & 127 & 127 & 4.88 & 6.19 & 0.79 & 48 & 57 & 53 \\
\hline Lincs. & 0.79 & 0.62 & 1.27 & 128 & 109 & 120 & 4.23 & 4.15 & 1.02 & 43 & 43 & 43 \\
\hline
\end{tabular}




\begin{tabular}{|c|c|c|c|c|c|c|c|c|c|c|c|c|}
\hline Middx. & 1.22 & 1.04 & 1.17 & 68 & 64 & 66 & 3.34 & 2.77 & 1.20 & 36 & 31 & 33 \\
\hline Monmouth & 0.39 & 0.31 & 1.24 & 97 & 84 & 91 & 4.53 & 4.34 & 1.05 & 44 & 44 & 44 \\
\hline Norfolk & 0.93 & 0.73 & 1.27 & 119 & 110 & 115 & 6.34 & 6.68 & 0.95 & 47 & 47 & 47 \\
\hline Northants & 0.73 & 0.55 & 1.32 & 106 & 83 & 96 & 5.71 & 5.47 & 1.04 & 44 & 43 & 43 \\
\hline Northumb. & 0.46 & 0.43 & 1.07 & 87 & 75 & 81 & 5.39 & 5.33 & 1.01 & 30 & 29 & 30 \\
\hline Notts. & 0.46 & 0.45 & 1.02 & 113 & 96 & 104 & 3.44 & 3.71 & 0.93 & 46 & 48 & 47 \\
\hline Oxon. & 1.00 & 0.65 & 1.54 & 117 & 89 & 105 & 6.90 & 6.10 & 1.13 & 56 & 53 & 54 \\
\hline Rutland & 0.98 & 0.69 & 1.42 & 152 & 122 & 139 & 4.13 & 3.65 & 1.13 & 43 & 34 & 39 \\
\hline Salop. & 0.64 & 0.54 & 1.18 & 93 & 87 & 90 & 4.64 & 4.39 & 1.06 & 52 & 51 & 52 \\
\hline Somerset & 0.81 & 0.64 & 1.26 & 93 & 84 & 89 & 6.98 & 6.89 & 1.01 & 48 & 48 & 48 \\
\hline S'th (Hants.) & 1.11 & 0.89 & 1.24 & 106 & 98 & 103 & 6.33 & 5.66 & 1.12 & 48 & 45 & 46 \\
\hline Staffs. & 0.47 & 0.44 & 1.08 & 100 & 95 & 97 & 2.89 & 2.79 & 1.04 & 42 & 41 & 42 \\
\hline Suffolk & 1.26 & 0.85 & 1.49 & 137 & 117 & 129 & 6.87 & 6.56 & 1.05 & 55 & 52 & 53 \\
\hline Surrey & 1.06 & 0.91 & 1.17 & 96 & 91 & 94 & 4.07 & 3.53 & 1.15 & 49 & 43 & 46 \\
\hline Sussex & 1.28 & 0.99 & 1.29 & 149 & 122 & 137 & 6.26 & 6.16 & 1.02 & 60 & 59 & 59 \\
\hline Warks. & 0.43 & 0.37 & 1.16 & 98 & 94 & 96 & 3.16 & 2.99 & 1.06 & 40 & 40 & 40 \\
\hline Westmor. & 0.67 & 0.61 & 1.11 & 79 & 80 & 80 & 4.53 & 3.98 & 1.14 & 46 & 42 & 44 \\
\hline Wilts. & 1.21 & 0.83 & 1.45 & 100 & 68 & 87 & 8.14 & 7.59 & 1.07 & 49 & 49 & 49 \\
\hline Worcs. & 0.47 & 0.40 & 1.17 & 95 & 93 & 94 & 4.02 & 3.85 & 1.04 & 48 & 46 & 47 \\
\hline York ER & 0.45 & 0.45 & 1.00 & 91 & 78 & 85 & 3.58 & 3.57 & 1.00 & 34 & 31 & 32 \\
\hline York NR & 0.43 & 0.42 & 1.04 & 83 & 87 & 85 & 4.13 & 4.16 & 0.99 & 37 & 37 & 37 \\
\hline York WR & 0.27 & 0.24 & 1.10 & 108 & 108 & 108 & 3.41 & 3.38 & 1.01 & 41 & 41 & 41 \\
\hline England & 0.71 & 0.58 & 1.23 & 102 & 90 & 97 & 4.57 & 4.39 & 1.04 & 45 & 44 & 45 \\
\hline Wales & 0.29 & 0.26 & 1.10 & 75 & 71 & 73 & 6.67 & 6.71 & 0.99 & 37 & 37 & 37 \\
\hline England and Wales & 0.68 & 0.56 & 1.23 & 102 & 90 & 96 & 4.71 & 4.54 & 1.04 & 44 & 43 & 44 \\
\hline
\end{tabular}

Notes: In 1851 London was incorporated within Middlesex. Monmouth was included in England at this time. Source: British Parliamentary Papers, 1852, vol. XXIII. 
TABLE 9

Indoor and outdoor relief in England and Wales, 1901 : seasonal variation and sex ratios, by county

\begin{tabular}{|c|c|c|c|c|c|c|c|c|c|c|c|c|}
\hline \multicolumn{7}{|c|}{ Indoor relief } & \multicolumn{6}{|c|}{ Outdoor relief } \\
\hline & \multicolumn{2}{|c|}{ \% of pop. relieved } & \multirow{2}{*}{$\begin{array}{c}\text { Ratio } \\
\text { Jan.:July }\end{array}$} & \multicolumn{3}{|c|}{ Sex ratio, adults } & \multicolumn{2}{|c|}{$\%$ of pop. relieved } & \multirow{2}{*}{$\begin{array}{c}\text { Ratio } \\
\text { Jan. .July }\end{array}$} & \multicolumn{3}{|c|}{ Sex ratio, adults } \\
\hline & 1 Jan. & $1 \mathrm{July}$ & & $1 \mathrm{Jan}$. & 1 July & Total & 1 Jan. & 1 July & & $1 \mathrm{Jan}$. & 1 July & Total \\
\hline Beds. & 0.51 & 0.40 & 1.28 & 165 & 140 & 153 & 2.68 & 2.72 & 0.99 & 46 & 44 & 45 \\
\hline Berks. & 0.80 & 0.69 & 1.16 & 142 & 123 & 133 & 1.47 & 1.47 & 1.00 & 51 & 50 & 50 \\
\hline Cambs. & 0.57 & 0.50 & 1.14 & 179 & 156 & 167 & 2.57 & 2.53 & 1.02 & 44 & 44 & 44 \\
\hline Cheshire & 0.55 & 0.49 & 1.12 & 133 & 115 & 124 & 1.48 & 1.50 & 0.99 & 38 & 37 & 37 \\
\hline Cornwall & 0.41 & 0.40 & 1.03 & 65 & 64 & 65 & 3.00 & 2.92 & 1.03 & 32 & 32 & 32 \\
\hline Cumb. & 0.51 & 0.48 & 1.07 & 162 & 144 & 153 & 1.94 & 1.86 & 1.04 & 40 & 38 & 39 \\
\hline Derby. & 0.42 & 0.38 & 1.11 & 178 & 153 & 166 & 1.79 & 1.77 & 1.01 & 45 & 46 & 46 \\
\hline Devon & 0.53 & 0.50 & 1.06 & 105 & 95 & 100 & 2.86 & 2.78 & 1.03 & 41 & 41 & 41 \\
\hline Dorset & 0.53 & 0.49 & 1.08 & 158 & 136 & 147 & 3.52 & 3.48 & 1.01 & 46 & 45 & 45 \\
\hline Durham & 0.44 & 0.41 & 1.07 & 162 & 153 & 158 & 1.54 & 1.58 & 0.98 & 43 & 44 & 43 \\
\hline Gloucs. & 0.69 & 0.67 & 1.04 & 117 & 106 & 111 & 2.35 & 2.28 & 1.03 & 41 & 40 & 41 \\
\hline Hereford & 0.70 & 0.66 & 1.07 & 198 & 167 & 183 & 3.37 & 3.31 & 1.02 & 49 & 46 & 48 \\
\hline Herts. & 0.61 & 0.52 & 1.17 & 173 & 150 & 162 & 2.58 & 2.59 & 0.99 & 42 & 41 & 42 \\
\hline Hunts. & 0.78 & 0.63 & 1.23 & 150 & 121 & 136 & 2.12 & 2.06 & 1.03 & 51 & 48 & 50 \\
\hline Kent & 0.75 & 0.64 & 1.16 & 170 & 147 & 159 & 1.66 & 1.63 & 1.02 & 40 & 40 & 40 \\
\hline Lancs. & 0.71 & 0.66 & 1.07 & 123 & 113 & 118 & 1.16 & 1.16 & 1.00 & 38 & 37 & 38 \\
\hline Leic. & 0.52 & 0.45 & 1.16 & 184 & 156 & 171 & 2.07 & 2.04 & 1.01 & 49 & 49 & 49 \\
\hline Lincs. & 0.41 & 0.36 & 1.15 & 183 & 164 & 174 & 2.84 & 2.79 & 1.02 & 44 & 44 & 44 \\
\hline London & 1.51 & 1.39 & 1.09 & 110 & 103 & 107 & 1.21 & 1.21 & 1.00 & 39 & 38 & 39 \\
\hline
\end{tabular}




\begin{tabular}{|c|c|c|c|c|c|c|c|c|c|c|c|c|}
\hline Middx. & 0.45 & 0.40 & 1.10 & 120 & 99 & 109 & 1.11 & 1.04 & 1.07 & 38 & 37 & 37 \\
\hline Norfolk & 0.67 & 0.64 & 1.05 & 127 & 122 & 124 & 3.25 & 3.20 & 1.02 & 42 & 42 & 42 \\
\hline Northants & 0.46 & 0.41 & 1.12 & 175 & 168 & 172 & 2.31 & 2.30 & 1.00 & 50 & 49 & 49 \\
\hline Northumb. & 0.39 & 0.38 & 1.04 & 115 & 104 & 110 & 1.35 & 1.33 & 1.02 & 42 & 41 & 41 \\
\hline Notts. & 0.46 & 0.40 & 1.14 & 174 & 167 & 171 & 1.90 & 1.88 & 1.01 & 49 & 49 & 49 \\
\hline Oxon. & 0.74 & 0.63 & 1.18 & 148 & 120 & 134 & 2.76 & 2.77 & 1.00 & 51 & 53 & 52 \\
\hline Rutland & 0.67 & 0.53 & 1.28 & 141 & 116 & 129 & 2.39 & 2.40 & 1.00 & 45 & 41 & 43 \\
\hline Salop. & 0.70 & 0.61 & 1.15 & 177 & 153 & 165 & 1.54 & 1.59 & 0.97 & 51 & 51 & 51 \\
\hline Somerset & 0.55 & 0.52 & 1.04 & 128 & 110 & 119 & 2.85 & 2.79 & 1.02 & 42 & 41 & 41 \\
\hline S'th (Hants.) & 0.68 & 0.61 & 1.11 & 130 & 120 & 125 & 2.13 & 2.14 & 0.99 & 40 & 40 & 40 \\
\hline Staffs. & 0.57 & 0.52 & 1.10 & 153 & 141 & 147 & 2.15 & 2.16 & 0.99 & 45 & 45 & 45 \\
\hline Suffolk & 0.63 & 0.56 & 1.12 & 172 & 153 & 163 & 2.87 & 2.78 & 1.03 & 50 & 48 & 49 \\
\hline Surrey & 0.65 & 0.54 & 1.20 & 129 & 108 & 119 & 1.15 & 1.14 & 1.01 & 40 & 40 & 40 \\
\hline Sussex & 0.74 & 0.65 & 1.14 & 151 & 130 & 141 & 2.02 & 1.99 & 1.01 & 43 & 42 & 43 \\
\hline Warks. & 0.74 & 0.68 & 1.09 & 123 & 115 & 119 & 1.22 & 1.25 & 0.97 & 49 & 50 & 49 \\
\hline Westmor. & 0.67 & 0.60 & 1.11 & 198 & 179 & 189 & 1.39 & 1.30 & 1.07 & 43 & 43 & 43 \\
\hline Wilts. & 0.71 & 0.61 & 1.17 & 153 & 131 & 142 & 2.86 & 2.82 & 1.01 & 47 & 47 & 47 \\
\hline Worcs. & 0.58 & 0.52 & 1.11 & 138 & 122 & 130 & 1.85 & 1.87 & 0.99 & 44 & 43 & 44 \\
\hline York ER & 0.54 & 0.50 & 1.07 & 166 & 143 & 155 & 2.16 & 2.19 & 0.99 & 40 & 40 & 40 \\
\hline York NR & 0.50 & 0.45 & 1.12 & 171 & 144 & 158 & 2.11 & 2.08 & 1.01 & 45 & 45 & 45 \\
\hline York WR & 0.41 & 0.38 & 1.08 & 147 & 132 & 140 & 1.29 & 1.30 & 0.99 & 42 & 42 & 42 \\
\hline England & 0.72 & 0.65 & 1.10 & 129 & 118 & 124 & 1.71 & 1.70 & 1.01 & 42 & 42 & 42 \\
\hline Wales & 0.38 & 0.34 & 1.12 & 154 & 142 & 148 & 2.55 & 2.54 & 1.00 & 35 & 35 & 35 \\
\hline England and Wales & 0.70 & 0.64 & 1.10 & 130 & 118 & 124 & 1.76 & 1.75 & 1.01 & 42 & 41 & 41 \\
\hline
\end{tabular}

Notes: By 1901 London was identified separately; Monmouth was now included among the Welsh counties. Source: British Parliamentary Papers, 1901, vol. XXV. 
Thomson's claim that workhouse occupancy showed little seasonal variation, we can see quite clearly from the snapshot of 1851 that it did, or at least it did in certain counties, notably Bedfordshire, Berkshire, Buckinghamshire, Cambridgeshire, Dorset, Essex, Hertfordshire, Huntingdonshire, Oxfordshire, Rutland, Suffolk and Wiltshire. In many, though not all, of these same counties, the sex ratio among workhouse inmates was considerably more skewed towards men in January than it was in July. For outdoor relief, there is far less seasonal variation, both in numbers relieved and in sex ratios, the figures being fairly consistently skewed towards women regardless of the season, though not without a degree of inter-county variation.

The data presented in Table 5, for England and Wales and for Hertfordshire, indicated considerable decline in the seasonality of indoor pauperism by the end of the century, though it still remained more of a problem in Hertfordshire, especially for men, than it did nationally. The relative degree to which it persisted county by county, if not its true depth, can again be established from the annual reports, and it comes as no surprise to find that the ratio between the number of indoor paupers on 1 January 1901 as compared to 1 July remained highest in most of the same counties as in 1851 , which - like Hertfordshire - had retained a considerable arable agricultural emphasis. ${ }^{60}$ By this time, however, sex ratios among indoor paupers that were significantly skewed towards men, particularly in the winter count, were now found in every English county with the single exception of Cornwall.

\section{CONCLUSION}

Poor old men have not been given the attention they deserve in recent writing on poverty in nineteenth-century England. Even the rise of the 'male breadwinner family' is all too often viewed only from the perspective of female exclusion from the workforce. But if the male-breadwinner family contributed towards the condemnation of women to a life of domestic drudgery, it condemned men to a life of hard physical toil, as well as to a weight of socio-psychological pressure that it is all too easy to underestimate. Despite his solid middle-class pedigree, Engels expressed this burden well in The condition of the working class in England through the relation of a conversation between Joe and Jack, where Jack passionately bemoans his sad plight as a house-husband of three years standing, reduced to 'women's work' - domestic chores - while his wife has become the breadwinner:

when I got married I had work plenty and thou knows I was not lazy ... And we had a good furnished house, and Mary need not go to work. I could work for the two of us; but 
now the world is upside down. Mary has to work and I have to stop at home and mind the childer, sweep and wash, bake and mend; and when the poor woman comes home at night, she is knocked up. Thou knows, Joe, its hard for one that was used different. $^{61}$

This, of course, reveals clearly a gender stereotyping of the malebreadwinner family as the right and natural state of affairs, an ideal that Engels perceived as having been subverted by the march of capitalist relations of production in the factory towns of the Midlands and north that he knew so well. ${ }^{62}$ His judgement could not be more categorical: 'Can anyone imagine a more insane state of things ...? And yet this condition, which unsexes the man and takes from the woman all womanliness ... this condition which degrades, in the most shameful way, both sexes, and, through them, Humanity, is the last result of our much praised civilization ....' ${ }^{\mathbf{6 3}}$

Engels' view of gender stereotypes and their subversion by the economics of industrial capitalism are the very same attitudes that underpinned the very different treatment afforded to men and women under the New Poor Law. But it was not in the industrial heartlands that the effects of those attitudes were most strongly felt, but in those areas that retained their agrarian bias for longer, particularly arable counties such as Hertfordshire. A more appropriate contemporary account, therefore, is that provided by Richard Jefferies in Hodge and his masters, published in 1880 , where he graphically describes the last days of an agricultural labourer: ${ }^{4}$

After all the ploughing and the sowing, the hoeing and the harvesting, comes the miserable end ... The limbs totter, the back is bowed, the dimmed sight can no longer guide the plough in a straight furrow, nor the weak hands wield the reaping hook. Hodge, who, Atlas-like, supported on his shoulders the agricultural world, comes in his old age under the dominion of his last masters at the workhouse ... His case came before the Board of Guardians ... In the result the old man was driven into the workhouse; muttering and grumbling, he had to be bodily carried to the trap, and thus by physical force was dragged from his home. In the workhouse there is of necessity a dead level of monotony - there are many persons but no individuals. The dining-hall is crossed with forms and narrow tables, somewhat resembling those formerly used in schools. On these at dinner times are placed a tin mug and a tin soupplate for each person; every mug and every plate exactly alike. When the unfortunates have taken their places, the master pronounces grace from an elevated desk at the end of the hall ... Plain as the fare was, it was better than the old man had existed on for years; but though better it was not his dinner. He was not sitting in his old chair, at his own table, round which his children had once gathered ... There was a garden attached to the workhouse, but it was not his garden [and] here he could not go outside the boundary - it was against regulations. ... At the workhouse the monotony weighed upon him ... When once an aged man gives up, it seems strange at first that he should be so utterly helpless. In the infirmary the real benefit of the workhouse reached him. The food, the little luxuries, the attention were far superior to anything he could possibly have had at home. But still it was not home ... The end came slowly; he ceased to exist by imperceptible degrees ... 
In nineteenth-century Hertfordshire, as in many other southern agricultural counties, a significant proportion of the elderly male population would 'cease to exist' in just such a manner. No doubt some women did too. But for many elderly women in nineteenth-century Hertfordshire, relief was available in the form of employment in a cottage industry, almshouse accommodation, the continuing receipt of out-relief and a far higher incidence of family support, and hence to a considerable degree poverty was gendered - in this county at least - though not in the way that we have become accustomed to believe.

Given the emphasis placed upon discrimination under the New Poor Law, the differential treatment according to gender, the prominence of elderly men in workhouses and the evidence of regional disparities, it is somewhat ironic that the French in the nineteenth century repeatedly pronounced that the English system of 'legal charity' was the epitome of the baneful effects of an indiscriminate, tax-based system of social welfare ${ }^{65}$ The wider implications of this discrimination, and the extent of variation by region and locality, remain to be explored. The withdrawal of outdoor relief from able-bodied men, however, allied to the seasonality of agricultural labour, must have had implications for the receptivity of the working population of Hertfordshire to the notion of the malebreadwinner family, particularly if - as was claimed in 1865 - the availability of work in the straw-plait and hat trades meant that 'a well ordered family will obtain as much if not more than the husband who is at work on the neighbouring farm ${ }^{6}{ }^{66}$ However, the withdrawal of women from the labour force in Hertfordshire in the later nineteenth century owed little to acceptance of the role of the male as breadwinner, still less to government regulation; it was simply a product of the decline of the plaiting trade under the influence of foreign competition. ${ }^{67}$ Rates of migration may also have been affected: in the rural parishes of the St Albans region of Hertfordshire men aged 40 and over appear to have had a higher propensity to migrate than did women, while the town of St Albans included larger numbers of elderly women who were migrants than it did men. ${ }^{68}$ It is possible that the former feature reflects the increasing difficulties experienced by older men in finding employment. The latter feature may partly have been a product of the attractiveness of urban living to women of independent means, but it might also reflect the wider opportunities found there for both employment and charitable relief. ${ }^{69}$ There may have been implications for levels of crime too. The annual returns of prisoners committed to Hertford County Gaol and Bridewell, and indictments at Hertford Quarter Sessions, suggest a distinct rise in levels of criminal activity across the second quarter of the nineteenth century, those indicted being overwhelmingly male labourers, although they were 
mostly young men rather than the elderly. ${ }^{70}$ How the vulnerability of elderly agricultural labourers affected notions of patriarchy and masculinity within rural families we can only speculate upon. Nevertheless, if it is true that by the late nineteenth century the 'Hodge stereotype' of the dull, ignorant and deferential agricultural labourer was giving way to a nobler perception which emphasized the rural worker's timeless strength, and the economic position of the agricultural labourer was also improving as real wages rose and rural depopulation proceeded in the 1880 s and 1890 s, it is possible that the continued prominence of elderly men among workhouse populations may have served to create an increasingly stark contrast across the generations. ${ }^{71}$

\section{ENDNOTES}

1 P. Slack, Poverty and policy in Tudor and Stuart England (London, 1988), 75-6; S. Hindle, On the parish? The micro-politics of poor relief in rural England c. 1550-1750 (Oxford, 2004), 273-4; M. Pelling, 'Who needs most to marry? Ageing and inequality among women and men in early modern Norwich', in L. Botelho and P. Thane eds., Women and ageing in British society since 1500 (Harlow, 2001), 31-42.

2 P. Thane, 'Women and the poor law in Victorian and Edwardian England', History Workshop 6 (1978), 33; P. Thane, Old age in English history: past experiences, present issues (Oxford, 2000), 193, 271-2; J. Burnette, 'An investigation of the female-male wage gap during the industrial revolution in Britain', Economic History Review 50 (1997), 257-9; P. Lane, 'A customary or market wage? Women and work in the East Midlands c. 1700-1840', in P. Lane, N. Raven and K. D. M. Snell eds., Women, work and wages in England, 1600-1850 (Woodbridge, 2004), 102-118.

3 In a recent historiographical survey Thane notes that the issue of gender 'has been surprisingly slow to enter studies of old age', but her continued over-riding concern with women is clearly signalled as she continues 'in view of the predominance of women among older people in many times and places'; see 'Social histories of old age and aging', Journal of Social History 37 (2003), 93-111, cited at 94.

4 These calculations are based upon the published census reports between 1801 and 1901, allied to data from births and deaths extracted from the Annual Reports of the Registrar General for Births, Marriages and Deaths, 1837-1901. Population totals are for the ancient county rather than the registration county. For a fuller summary of the demographic development of Hertfordshire in the nineteenth century see N. Goose, 'Population 1801-1901', in D. Short ed., An atlas of Hertfordshire history (Hatfield, forthcoming, 2006),

5 D. Walker, General view of the county of Hertford presented to the Board of Agriculture, quoted in The Victoria County History of Hertfordshire, 4 vols (London, 1904-1914), vol. 2, 129. Young also noted that arable cultivation was 'the great object of Hertfordshire husbandry', while the returns of 1867 reveal that for both cattle and sheep Hertfordshire stood towards the bottom of the rank order of counties in terms of livestock per acre; see A. Young, General view of the agriculture of the county of Hertfordshire (1804, repr. Newton Abbot, 1971), 55; G. E. Mingay ed., The agrarian history of England and Wales, vol. VI: 1750-1850 (Cambridge, 1989), Table III.10, p. 1065. 
6 For a fuller discussion see N. Goose, Population, economy and family structure in Hertfordshire in 1851, vol. 2: St Albans and its region (Hatfield, 2000), 116-19, and N. Agar, 'The Hertfordshire farmer in the age of the industrial revolution', in D. JonesBaker ed., Hertfordshire in history (Hertford, 1991, repr. Hatfield, 2004), 247-64, and Behind the plough: agrarian society in nineteenth-century Hertfordshire (Hatfield, 2005).

7 For a useful overview see T. Rook, A history of Hertfordshire (Chichester, 1984). See also Victoria County History of Hertfordshire, vol. 4, 173-280; W. Branch Johnson, The industrial archaeology of Hertfordshire (Newton Abbot, 1970). For the strawplait and hat trades, see N. Goose, Population, economy and family structure in Hertfordshire in 1851, vol. 1: The Berkhamsted region (Hatfield, 1996), and St Albans and its region.

8 The key Elizabethan poor relief statute of 1598 defined them as the 'lame ympotent olde blynde and such other amonge them being poore and not able to work'; quoted in Hindle, On the parish?, 227.

9 There is a vast literature on the subject, useful recent surveys including L. H. Lees, The solidarities of strangers: the English poor laws and the people, 1700-1948 (Cambridge, 1998), 115-52, 177-217; A. Kidd, State, society and the poor in nineteenth-century England (Basingstoke, 1999), 24-45; D. Englander, Poverty and poor law reform in 19th century Britain, 1834-1914 (London, 1998), 5-30; and A. Brundage, The English poor laws, 1700-1930 (Basingstoke, 2002), 61-89.

10 S. King, "“Meer pennies for my baskitt will be enough": women, work and welfare, 1770-1830', in Lane, Raven and Snell eds., Women, work and wages, 126, 128, 132-4, $136-7$.

11 British Parliamentary Papers (hereafter BPP) 1834, XXVII, 230; XXXIX, part III, $156 \mathrm{a}-157 \mathrm{a}$.

12 BPP, 1833, V, 30-1, 339.

13 M. Rose, The relief of poverty, 1834-1914 (2nd edition, Basingstoke, 1986), 16-17 and Appendix A, p. 50; M. MacKinnon, 'English poor law policy and the crusade against outrelief', Journal of Economic History 47 (1987), 603-25.

14 Even the wealth of data extracted from the various nineteenth and early-twentiethcentury reports by Williams, upon which so many historians rely, fails to provide a breakdown by gender, except for tabulation of the number of widows with dependent children on outdoor relief; see K. Williams, From pauperism to poverty (London, 1981), 145-233 (widows with dependent children at 198).

15 Lees, Solidarities of strangers, 143-4.

16 Williams, From pauperism to poverty, 68-75, cited at 75; W. Apfel and P. Dunkley, 'English rural society and the New Poor Law, 1834-47', Social History 10 (1985), 39-48.

17 A. Digby, Pauper palaces (London, 1978), 110-14; A. Digby, 'The rural poor law', in D. Fraser ed., The New Poor Law in the nineteenth century (London, 1976), 149-70; A. Digby, 'The labour market and the continuity of English social policy after 1834: the case of the eastern counties', Economic History Review 28 (1975), 69-83. See also Rose, Relief of poverty, 13-14; Brundage, English poor laws, 79; and M. E. Rose,'The allowance system under the New Poor Law', Economic History Review 19 (1966), 607-16, where particular though not exclusive emphasis is placed upon continuation of outdoor relief in aid of male wages in the northern manufacturing Unions.

18 Englander, Poverty and poor law reform, 14; K. D. M. Snell, Annals of the labouring poor: social change and agrarian England 1660-1900 (Cambridge, 1985), 131.

19 Lees, Solidarities of strangers, 213-14. 
20 BPP, 1852-1853, L, 98, 102; Williams, From Pauperism to Poverty, Table 4.10, p. 182.

21 Lees, Solidarities of strangers, 146.

22 Rose, Relief of poverty, 16.

23 BPP 1890-1891, XXXIII, 472-5.

24 For a similar emphasis upon the prominence of the elderly, and particularly the male elderly, in workhouses from the 1860s, and appreciation of regional variation, see MacKinnon, 'English poor law policy', 604.

25 Workhouse data from Hertfordshire Census Enumerators' Books, The National Archive, Kew (hereafter NA), HO 107/1701-1716; county age structure calculated from 1851 census report, BPP, 1852-1853, LXXXVIII, part I, 139.

26 Workhouse data from Hertfordshire Census Enumerators' Books, NA, RG 12/ 1052-1127; county age structure calculated from 1891 census report, BPP, 1893-1894, CVI, 86.

27 N. Goose, 'Workhouse populations in the mid-nineteenth century: the case of Hertfordshire', Local Population Studies 62 (1999), Table 3, 65.

28 This represents a marginal upward revision (from 72 per cent) of the calculation for 11 workhouses given in Goose, 'Workhouse populations', 61.

29 Calculation from Hertfordshire Archives and Local Studies (County Hall, Hertford), BG HAT, Hatfield Union Admissions and Discharges Register.

30 These calculations, from Hertfordshire Census Enumerators' Books (see n. 25) are tentative, for the Bishop's Stortford and Watford Unions list large numbers of 'labourers', who may have been general labourers, or agricultural labourers, or both.

31 Food and Agriculture Organization, 'Energy and protein requirements: report of a joint FAO/WHO/UN expert consultation', Technical Report Series 724 (Geneva, 1975), cited in R. Floud, The people and the British economy 1830-1914 (Oxford, 1997), 106.

32 Ibid.

33 Goose, 'Workhouse populations', 61.

34 Thane, Old age, 273, 275.

35 M. Woollard, 'The employment and retirement of older men, 1851-1881; further evidence from the census', Continuity and Change 17 (2002), 444-6, 450.

36 This must be a minimum figure: data analysed for 1931 show a considerable discrepancy between occupations reported in the census of that year and actual earning potential, and this is likely to apply just as strongly in the nineteenth as in the early twentieth centuries; see Woollard, 'Employment and retirement', 444 and sources cited therein. However, as the number active excludes institutional residents, but these are included in the sample total, this will serve to understate the proportions active, particularly in the higher age groups; ibid., 444-5.

37 If those of independent means are excluded from the 'inactive' population the figures become 23 per cent and 19 per cent for 1851 and 1881 respectively.

38 The proportions inactive, excluding those living on independent means, for those $60+$, $65+$ and $70+$ for the Bishop's Stortford Union were 24.1 per cent, 31.8 per cent and 40.4 per cent respectively, and for the Royston Union 21.6 per cent, 29.9 per cent and 42.1 per cent respectively.

39 For references see notes 25, 26 and 29; also Woollard, 'Employment and retirement', 444 and n. 21.

40 G. Clark, 'Farm wages and living standards in the Industrial Revolution: England, 1670-1869', Economic History Review 54 (2001), 489. The evidence produced to support this statement is taken from one Essex parish, Ardleigh, prior to the introduction of the New Poor Law, and from farm accounts for the period 1640-1789 (ibid., 489-91). This view, of course, flies in the face of received opinion, particularly for the 
corn-growing, southern counties; see, for example, G. E. Mingay ed., The agrarian history of England and Wales, vol. VI: 1750-1850 (Cambridge, 1989), 692-3; and Alan Armstrong, Farmworkers in England and Wales: a social and economic history 1770-1980 (London, 1988), 63-6, 98-9.

41 Goose, 'Workhouse populations', 65-6.

42 Similar employment is indicated in Broxbourne, Cheshunt, Hertford, St Ippollitts, Redbourn, Sacombe, Shenley, Stevenage and Westmill.

43 BPP, 1834, XXX, 217-27, and Hatfield and its people: the story of a new town, a garden city, an old village, a historic house, the farms and countryside of a Hertfordshire parish, publ. by the Hatfield branch of the WEA (1961), 23.

44 BPP, 1834, XXXII, 217, 224, 225 (parishes of St Michael, Shenley and Stanstead Abbots). For a wider appraisal of seasonality as reflected in the 1834 answers to rural queries, which collates the evidence for ten grain-producing counties, see G. R. Boyer, An economic history of the English poor law 1750-1850 (Cambridge, 1990), $88-90$.

45 The average additional number of able-bodied men in workhouses in 1850-1852 in Hertfordshire was 239, compared an additional 149 not able; for England and Wales the figures were 4,871 and 275 respectively. For each successive period there were more additional men classed as not able than were classed as able-bodied. For Hertfordshire for the five periods from 1860-1862 to 1900-1902, respectively, 130 able, 142 not able; 133 able, 209 not able; 90 able, 161 not able; 89 able, 151 not able; 62 able, 92 not able; for England and Wales 3,744 able, 4,461 not able; 5,560 able, 6,980 not able; 4,599 able, 8,786 not able; 4,895 able, 11,068 not able; 5,695 able, 9,321 not able (from BPP, Annual Reports of the Poor Law Board and Local Government Board).

46 For a detailed study of the straw-plait and hat trades in the Berkhamsted and St Albans Superintendent Registrars' Districts see Goose, The Berkhamsted region and St Albans and its region.

47 Goose, 'Workhouse populations', 59-60. This was a tendency only, and is not clear-cut for all workhouses.

48 The rules for eligibility were usually laid down by the original donor who established the almshouse or almshouses, and these were enforced by the trustees. There are surprisingly few academic studies of almshouses in either the early modern or the modern period. For a valuable study of eighteenth-century Oxford, however, see A. Tompkins, 'Almshouse versus workhouse: residential welfare in 18th-century Oxford', Family \& Community History 7 (2004), 46-58.

49 A gazetteer has been compiled, largely from the reports of the Charity Commissioners, supplemented by the Abstracts of the Returns of Charitable Donations for the Benefit of Poor Persons ... 1786-1788: BPP, 1833, XVIII, 175; BPP, 1834, XXI, 237; BPP, 1835, XXI, 273; BPP, 1816, XVI, A-1, 483-504. I am grateful to Deana Styles for compiling the data upon which this analysis is based.

50 Not all of these almshouses are identifiable in the 1851 census returns, where they are often not named, but as most of them are found in the Charity Commissioners' Reports for Hertfordshire of $1833-1835$, and as there is no reason to believe that the foundations crumbled in the later 1830 s or 1840 s, the number of places available can validly be compared with the evidence of the census of that year. The role of this form of philanthropy in providing support to the elderly poor in the nineteenth century, to women in particular, has been badly neglected. For recognition of the potential importance of almshouses to elderly women, however, see D. Thompson, 'Welfare and the historians', in L. Bonfield, R. Smith and K. Wrightson eds., The world 
we have gained: essays presented to Peter Laslett on his seventieth birthday (Oxford, 1986).

51 D. Thomson, 'Workhouse to nursing home: residential care of elderly people in England since 1840', Ageing and Society 3 (1983), 64-5.

52 J. Burnett ed., Destiny obscure: autobiographies of childhood, education and family from the 1820s to the 1890s (London, 1982), 219.

53 Calculations from Hertfordshire Census Enumerators' Books, 1851, NA, HO 107/1707 fos. 1-538: HO 107/1713, fos. 1-585. For Oxfordshire Flora Thompson's reminiscences emphasizes the difficulty that children might have in accommodating two parents in already overcrowded cottages, though she does not suggest gender bias; see F. Thompson, Lark Rise to Candleford (Penguin edn, Harmondsworth 1973, 1st publ. Oxford, 1939), 75.

54 M. Anderson, 'Households, families and individuals: some preliminary results from the national sample from the 1851 census of Great Britain', Continuity and Change 3 (1988), 426. For a more detailed discussion of the St Albans results see Goose, St Albans and its region, 175-9.

55 Parts of the Royston Superintendent Registrar's District (SRD) that lay outside of Hertfordshire are excluded from this analysis, and hence the correspondence with the catchment area for Royston workhouse is only approximate. For a particularly sensitive analysis of family support for the elderly see P. Thane, 'Old people and their families in the English past', in M. Daunton ed., Charity, self-interest and welfare in the English past (London, 1996), 113-38, and Old age, 287-307.

56 B. Reay, Rural Englands: labouring lives in the nineteenth century (Basingstoke, 2004).

57 F. Purdy, 'On the earnings of agricultural labourers in England and Wales, 1860', Journal of the Royal Statistical Society 24 (1861), 330-42; A. W. Fox, 'Agricultural wages in England and Wales during the last fifty years', Journal of the Royal Statistical Society 66 (1903), Appendices I-III, pp. 323-41; C. S. Orwin and B. I. Felton, 'A century of wages and earnings in agriculture', Journal of the Royal Statistical Society 92 (1931), 233-46. See also Armstrong, Farmworkers, 118-23.

58 Thomson, 'Workhouse to nursing home', 43-69.

59 Calculated from BPP, 1852, XXIII, 98-105; BPP, 1901, XXV, 243-5, 307-9.

60 Weekly data available in the Annual Reports of the Poor Law and Local Government Boards, which has not yet been subjected to systematic analysis, suggest that the nadir of seasonal employment occurred in late January and early February, which is not captured by the data available for 1 January. The high point of employment, however, matches the 1 July return very closely.

61 F. Engels, The condition of the working class in England in 1844 (Panther edn, St Albans, 1969), 174.

62 Ironically, this stands in complete contradiction to the usual Marxist construction of the progress of capitalism and its marginalization of women in the labour force; see S. Horrell and J. Humphries, 'Women's labour force participation and the transition to the male-breadwinner family, 1790-1865', in P. Sharpe ed., Women's work: the English experience 1650-1914 (London, 1998), 177 and sources cited therein.

63 Engels, The condition of the working class, 174.

64 R. Jefferies, 'Hodge's last masters', in Hodge and his masters (repr. Stroud, 1992, 1st publ. 1880), 232-7. For a similar emotive account from Oxfordshire and other references to the vulnerability of the elderly to removal to the workhouse before the introduction of old age pensions, see Thompson, Lark Rise, 88-90, 96, 428-9. 
65 T. B. Smith, 'The ideology of charity, the image of the English poor law, and debates over the right to assistance in France, 1830-1905', Historical Journal 40 (1997), 997-1032.

66 A. J. Tansley, 'On the straw plait trade', Journal of the Society of Arts IX (1860), 73-4.

67 Goose, St Albans and its region, 70-4.

68 Ibid., $138-41$.

69 Ibid., 92-4, 141.

70 M. Stevens, 'The "characteristics" of crime in Hertfordshire, c. 1825-50', unpublished MA dissertation, University of Hertfordshire, 2003.

71 M. Freeman, 'The agricultural labourer and the "Hodge" stereotype, c. 1850-1914', Agricultural History Review 49 (2001), 172-86. 